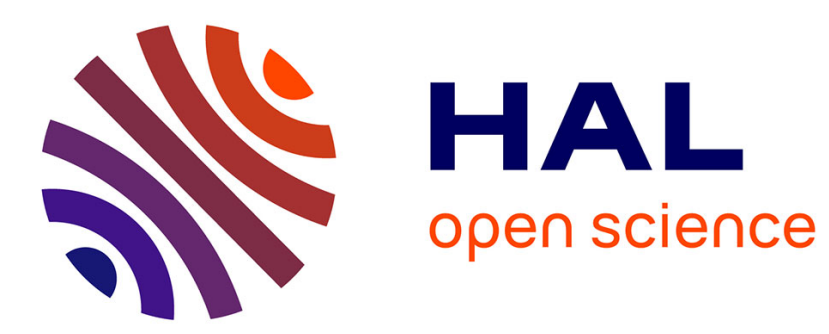

\title{
LCA applied to perennial cropping systems: a review focused on the farm stage
}

Cécile Bessou, Claudine Basset-Mens, Thierry Tran, Anthony Benoist

\section{To cite this version:}

Cécile Bessou, Claudine Basset-Mens, Thierry Tran, Anthony Benoist. LCA applied to perennial cropping systems: a review focused on the farm stage. International Journal of Life Cycle Assessment, 2013, pp.340-361. 10.1007/s11367-012-0502-z · cirad-00745775v2

\section{HAL Id: cirad-00745775 http://hal.cirad.fr/cirad-00745775v2}

Submitted on 8 Jan 2013

HAL is a multi-disciplinary open access archive for the deposit and dissemination of scientific research documents, whether they are published or not. The documents may come from teaching and research institutions in France or abroad, or from public or private research centers.
L'archive ouverte pluridisciplinaire HAL, est destinée au dépôt et à la diffusion de documents scientifiques de niveau recherche, publiés ou non, émanant des établissements d'enseignement et de recherche français ou étrangers, des laboratoires publics ou privés. 


\title{
LCA Applied to Perennial Cropping Systems: a Review Focused on the Farm Stage
}

\author{
C. Bessou ${ }^{1}$, \\ C. Basset-Mens ${ }^{2}$,
}

Th. $\operatorname{Tran}^{3}$,

A. Benoist ${ }^{4}$

${ }^{1}$ CIRAD, UPR Perennial Crops, Av. de l’Agropolis, TA B-34/02, 34398 Montpellier Cedex 5, France

${ }^{2}$ CIRAD, UPR Hortsys, Boulevard de la Lironde, TA B-103/PS4, 34398 Montpellier Cedex 5, France

${ }^{3}$ CIRAD, UMR Qualisud, CSTRU, Kasetsart University Agro-industry build. 3, Floor 8 Jatujak, Bangkok 10900, Thailand

${ }^{4}$ CIRAD, UPR Biomass Energy, 73, rue Jean-François Breton, TA B-42/16, 34398 Montpellier Cedex 5, France

Corresponding author: Cécile Bessou; Tel. +33 4676144 87; Fax. +33 4676165 90; E-mail:

cecile.bessou@cirad.fr

Retrieve the publisher version at:

http://link.springer.com/search?query=bessou\&search-within=Journal\&facet-journal-id=\%2211367\%22

\section{Abstract}

- Purpose: Perennial crops globally provide a lot of fruit and other food products. They may also provide feedstock for bioenergy and have been, notably to this end, the subject of several LCA-based studies mostly focusing on energy and GHG balances. The purpose of this review was to investigate the relevance of LCAs on perennial crops, especially focusing on how the perennial crop specificities were accounted for in the farm stage modelling.

- Methods: More than one hundred papers were reviewed covering 14 products from perennial crops: apple, banana (managed over several years), orange and other citrus fruits, cocoa, coconut, coffee, grape fruit, Jatropha oil, kiwi fruit, palm oil, olive, pear, and sugarcane. These papers were classified into three categories according to the comprehensiveness of the LCA study and depending on whether they were peer-reviewed or not. An indepth analysis of the goal and scope, data origin for farming systems, modelling approach for the perennial cropping systems, and methods and data for field emissions helped reveal the more critical issues and design some key recommendations to account better for perennial cropping systems in LCA.

- Results and discussion: In the vast majority of the reviewed papers, very little attention was paid on integrating the perennial cropping cycle in the LCA. It is especially true for bioenergy LCA-based studies that often mostly focused on the industrial transformation without detailing the agricultural raw material production, although it might contribute to a large extent to the studied impacts. Some key parameters, such as the length of the crop cycle, the immature and unproductive phase, or the biannual yield alternance, were mostly not accounted for. Moreover the lack of conceptual modelling of the perennial cycle was not balanced by any attempt to represent the temporal variability of the system with a comprehensive inventory of crop managements and field emissions over several years.

- Conclusions: According to the reviewed papers and complementary references, we identified the gaps in current LCA of perennial cropping systems and proposed a road map for scientific researches to help fill-in the knowledge-based gaps. We also made some methodological recommendations in order to account better for the perennial cycle within LCA considering the aim of the study and data availability.

Keywords: Life cycle assessment, perennial crops, agroforestry, agricultural inventory, critical review, methodological development, recommendations, scientific challenges 


\section{Introduction}

There is no unique and consensual definition of perennial plants or perennials. According to diverse sources, perennials live for more than two years, at least five years ${ }^{1}$, or simply live for many years ${ }^{2}$. Perennials are either herbaceous which survive winter as underground storage or perennating organs, or woody perennials whose tissues persist above ground. In between, palm trees (Arecaceae) are herbaceous whose tissues also persist above ground. From the point of view of agricultural management, perennial crops mean that i) the agricultural land allocated to perennials is not or no longer part of the crop rotation during several years, and ii) the cropping system must be planned over years, even decades, considering that some initial parameters such as seedling quality, land preparation, planting density etc., may have long-term or delayed impacts occurring up to years after the implementation. Taking oil palm management for instance, the alleviation of stress factors impacts upon yield for the subsequent 40 months (Härdter and Fairhurst 2003). From the wider perspective of the agroecosystem functioning, the specificities of perennial crops also induce long-term complex and evolving interactions with the ecosystem. The expansion of the root system in many directions down to deep soil layers (e.g. the quaternary and ascending secondary roots of oil palm In Härdter and Fairhurst (2003)) influences both long-term bio-geochemical nutrient cycles and fertilisation strategy. The variations of the soil supply in mineral elements may induce impacts at different time scales, for instance chlorine supply for coconut trees has cumulative effects on the four-year maturation of the fruits and heightens the trees' sensitivity threshold to water stress over several years (Bonneau 1998). The resilience of pests and diseases may jeopardise re-planting etc. These examples only give a partial insight into the complexity of perennial cropping systems and their interactions with the ecosystem. In contrast to this high diversity of risks and opportunities, perennial cropping systems usually are over-simplified when assessing their environmental impacts.

The environmental impacts of some perennials have been lately assessed notably in the context of their use as energy crops. Particular assets of perennials that qualify them as good feedstock for bioenergy are their high yields and relative low nutrients requirements (Jorgensen and Mortensen 1997; Lewandowski et al. 2003). Nevertheless, the environmental impacts of these crops are still debated and need to be better understood (Monti et al. 2009). In the bioenergy field, the emphasis has been put on the comparison of greenhouse gas and energy balances or use among diverse fuel sources. To this end, the Life Cycle Assessment (LCA) methodology has been widely used (Farrell et al. 2006; JRC et al. 2008; ADEME 2010) but cultivation was often secondary in bioenergy studies (Monti et al. 2009). LCA was originally mostly developed for site-independent industrial productions, which led to many methodological problems for agricultural LCA. In particular, agricultural data sets are time and site (soil-climate) dependent, which implies a great uncertainty in extrapolation of the linear models commonly used in LCA. Case studies and methodological developments have shown how to overcome part of the difficulties in agricultural LCA, notably while better considering the specificities of agricultural systems (Audsley et al. 1997; Basset-Mens et al. 2006; Bessou et al. 2012) or better modelling the impact of land use change (Weidema 2001; Milà i Canals et al. 2007; Brandão et al. 2011; Brandão and Milà i Canals 2012;

\footnotetext{
${ }^{1}$ http://ec.europa.eu/agriculture/envir/report/fr/lex_fr/report.htm

${ }^{2}$ http://botanydictionary.org/perennial.html
} 
Milà i Canals et al. 2012). However, there are to date no publications referring to methodological developments for a better integration of the agronomical specificities of perennial crops into LCA studies and models.

Beside energy crops, the need to assess the environmental impacts of agricultural crops has also been spreading out to a large range of agricultural commodities. The French Government has recently launched a national programme aiming to label food products with indicators of their environmental impacts (Koch et al. 2010). LCA is the chosen methodology within this programme as it notably makes it possible to compare the impacts of a same product produced in different regions. Among common food products, a great share comes from perennial crops, such as various fruits, coffee, cocoa, various condiments etc. Palm oil and wine for instance were among the top five exported commodities worldwide in monetary terms in 2008 (FAOSTAT $2008^{3}$ ). Nevertheless, only scarce information is available on the environmental performance of these production systems.

The objectives of this paper are:

a. To assess the state of the art of published LCA studies on perennial crops paying particular attention to the way the agricultural production is considered (methods, assumptions, data origin...) and;

b. To make some recommendations in terms of scientific challenges for applying LCA to perennial cropping systems.

\section{State of the art of LCA applied to perennial cropping systems and products}

\subsection{Method of literature review}

This review was based on available papers from the literature covering "full” or partial LCA studies for perennial cropping systems. Studies assessing at least four impact categories are considered here as "full” LCA in contrast to those focusing only on energy or greenhouse gas balances. The literature review was done through the following e-resources: the Web of Science, Science Direct, OvidSP, and Google Scholar. Research key words were “LCA” or "Life Cycle Assessment” combined with each encountered agricultural product, after a first screening with the key word "perennial”. Among the diversity of perennial cropping systems and products, we could not sink for an exhaustive review of all existing LCA studies, but we tried at least to be exhaustive on the peer-reviewed articles on full LCA for the agricultural products found in the literature, i.e. 14 products from perennial crops that were the subject of at least one peer-reviewed LCA study: apple, banana (managed over several years), orange and other citrus fruits, cocoa, coconut, coffee, grape fruit, Jatropha oil, kiwi fruit, palm oil, olive, pear, and sugarcane. About 155 references were overviewed. The most relevant publications, roughly 103 references, were classified into three categories: full LCA study published in peer-reviewed journals (39), partial LCA study published in a peer-reviewed journals (46), and not peer-reviewed LCA studies (18). We did not aim at reaching an exhaustive inventory of papers in the last two categories, which were seen more as complementary information to the papers falling in the first category. The remaining 52 references were interesting papers on the methodological aspects of an application of LCA to cropping systems that were also

\footnotetext{
${ }^{3}$ Data retrieved from http://faostat.fao.org
} 
included in the analysis.

Full LCA studies were analysed in depth considering five key aspects:

- goal and scope;

- data origin for farming systems;

- modelling approach for the perennial cropping systems;

- methods and data for field emissions;

- selected impact categories and methods and LCIA results.

Partial LCA studies were also analysed for their possible methodological interest regarding the modelling of perennial cropping systems in LCA, especially when full LCA studies were lacking. Finally, a particular focus was put on cradle-to-farm-gate LCA studies. An overview of 70 full and partial peer-reviewed LCA studies is presented in Table 1 with relevant information on key parameters. To limit the length of Table 1, not all the reviewed partial LCA studies are presented (notably on sugarcane and palm oil), although they were included in the analysis.

\subsection{General overview of selected papers}

\subsubsection{Goal \& scope}

Defining the Goal \& Scope is the first step of a LCA and can be seen as the most important one, since it defines initial and critical choices that determine the working plan of the entire LCA (Guinée et al. 2001; Jolliet et al. 2005). The Goal \& Scope phases of 70 in-depth reviewed papers are listed in Table 1. Overall, LCAs are quite recent. The oldest referred full LCA studies were published in 2003. It reveals the relative recent use of LCA methodology within the frame of environmental assessment of agricultural products. In particular, LCA has become a commonly used methodology to assess the greenhouse gas (GHG) and energy balance in the field of bioenergy. Most LCAs on Jatropha oil, palm oil, and sugarcane essentially aimed at comparing bioenergy systems based on these products with other energy sources and are partial LCAs. Roughly $60 \%$ of these studies are partial LCAs. In the case of palm oil, $74 \%$ of the reviewed studies assess palm oil-based bioenergy impacts. Among the rest of reviewed LCAs, the proportion of partial studies is lower ( 50\%), but again partial LCAs particularly focus on energy and GHG balances.

The geographic scope of the studies is representative of the current world supply share. As an example, among the 27 studies on oil palm 22 studies are located in South East Asia, the main world supply region, the last ones being focused either on South America ( Koch 2003; da Costa et al. 2006; Angarita et al. 2009; de Souza et al. 2010) or Africa ( Martinez et al. 2010; Achten et al. 2010b). The geographical coverage of studies on Jatropha is more disparate (India, Thailand, China or Ivory Coast) since the production is more prospective. LCA on cocoa is based on a Ghana data set, and LCAs on coffee are based on data sets from Brazil, Colombia and Vietnam, three of the main producing countries. One LCA on banana from Costa Rica and Ecuador was reviewed. Finally, LCAs on apple, citrus, grape, olive, pear, and kiwifruit are mostly related to product systems in temperate countries, except for one study on Brazilian citrus (Coltro et al. 2009).

System boundaries vary a lot within and among product chains. For transformed products, such as palm and Jatropha oils, coffee, cocoa or sugarcane for instance, the system boundaries include some industrial stages, 
being so-called "cradle-to-mill gate” assessments. Within these "cradle-to-gate” assessments, variations are related to whether the product chain includes import/export (Ramjeawon 2004) or focuses on some specific aspects of the transformation such as comparative processes or packaging (Humbert et al. 2009; Busser and Jungbluth 2009; Contreras et al. 2009). In the case of coffee, two of the LCAs include distribution and consumption steps, due to the interest of the coffee industry in comparing different forms of packaging/consumer behavior combinations (e.g. ground, instant, capsule coffees). A majority of studies on Mediterranean horticultural products also cover systems wider than the farm, including processing and distribution steps. The fragile status of fresh fruits and their possible destruction after farm gate have implications on their life cycle and corresponding environmental impacts. This makes the inclusion of post-farm gate processes important to include if the objective is to understand the global impact up to consumption. In the fresh fruit LCAs, the quality of the food products is considered for fruits eaten raw and dedicated to export (Milà i Canals et al. 2006; Sim et al. 2007). In the case of agricultural production for energy purpose, some LCAs include the use of the resulting bioenergy, being so-called "cradle-to-grave" assessments or "cradle-to-wheel” in the case of biofuels. For palm oil for instance, almost half of the reviewed bioenergy LCAs are "cradle-to-wheel” assessments including the transformation of palm oil into biodiesel and its consumption by varying vehicles, although only two studies encompass a specific assessment of exhaust gases in Malaysia (Choo et al. 2011) and Thailand (Pleanjai et al. 2009). The vast majority of the studies reviewed (73\%) do not include the impact of land use change. This proportion is lower in the case of palm oil (42\%) for which different approaches were used, either the IPCC guidelines (2006), carbon debt (Gibbs et al. 2008), or other methods (Henson 2004; Achten et al. 2010b). Among the studies considering land use changes, only one assesses the indirect impacts (Schmidt 2007).

Across the commodities, very few studies are "cradle-to-farm gate" assessments that specifically assess the impacts of varying agricultural managements on the environment. These studies provide a more detailed description of cropping systems (Sanjuan et al. 2005; Mouron et al. 2006a); in particular some studies ( $10 \%$ of reviewed studies) specifically aimed at comparing agricultural practices or producing data sets at the regional level to serve as references for derivative products (Coltro et al. 2006; Schmidt 2007; Zulkifli et al. 2009; Renouf et al. 2010).

Most studies (90\%) do not include capital goods or human labour. Exceptions are the study from Angarita et al. (2009) that includes both of them, and two studies including worker transportation (Harsono et al. 2011) or human labour (Ndong et al. 2009). Only in the latter study does human labour contribute significantly to the impacts due to very low-tech production systems. Some other studies include capital goods either fully (Milà i Canals et al. 2006; Schmidt 2007; Renouf et al. 2008; Luo et al. 2009; Achten et al. 2010a; Ju and Chen 2011; Renouf et al. 2010; Choo et al. 2011) or partially (Gmünder et al. 2010).

In the case of industrial transformed products, there is quite a clear consensus on using system expansion regarding the residues used to provide energy within the mill (shell and fiber, sugarcane bagasse) or the byproducts used as fertilisers (empty fruit bunches, palm oil mill effluent, sugarcane filter cake or waste water). System expansion is indeed very intuitive when dealing with co-products that are directly valued within the production system. However, the handling of co-products going outside of the production system is more diverging and not always clearly stated. In some studies, the allocation ratios vary with the type of co-product. In 
the case of palm oil, there are ratios on mass, economy or energy values for kernel oil, palm stearin or glycerin; respectively (Papong et al. 2010). Across product chains, allocation is primarily based on economic ratio. It is especially true for fruits produced in temperate region such as apple or grape. However, in the case of LCAs of bioenergy chains, mass or energy ratios are more dominant. In other studies, allocation is either not considered or no clear allocation rules are specified. Overall the large variations in system boundaries and co-product allocations make it very difficult to compare the studies.

\subsubsection{Key findings and contribution analyses}

As already mentioned, the system boundary varies a lot among the reviewed studies for each crop and the lack of transparency behind aggregated data makes any attempt to compare their results highly hypothetical, even when focusing on the impact of global warming, which was the only impact assessed in most studies. Furthermore, among the studies that assess a wider range of environmental impacts, applied methods also vary (Table 1). Still, general tendencies can be identified, first across the reviewed studies, then for some crops individually.

Across the studied crops, the farm stage globally is a main contributor to the following impact categories: global warming, eutrophication, and toxicity impacts. Even in the studies with a wide scope, such as the three studies on coffee in which the consumption stage is more impacting, or some studies on fruits with high impacts of the industrial stage (Salomone 2003; Cappelletti et al. 2010; Humbert et al. 2009; Busser and Jungbluth 2009), the farm stage remains of paramount importance regarding these impact categories. Exceptions may be coconut, for which the impact of the farm stage was considered in the two studies as negligible due to no mechanisation and no chemical use (Hirsinger et al. 1995; Tan et al. 2004). The hotspots of emissions contributing to the three above-mentioned impact categories are the production and use of fertilisers, notably for global warming and eutrophication, and pesticide and fertiliser uses for their toxicity impacts. These hotspots show how low-tech farm stages can still greatly contribute to such impact categories, sometimes as unintended consequence of government policies to increase yields through subsidised use of chemicals (Ntiamoah and Afrane 2008).

Taking a closer look at palm oil, the farm stage contributes to the major part of all potential impacts (Yusoff and Hansen 2007; Pleanjai et al. 2009; Arvidsson et al. 2010), except for respiratory inorganics primarily due to boiler emissions in the mill (Yusoff and Hansen 2007). The large contribution of the farm stage is due to the combined effects of 1) high chemical and energy inputs in the field and subsequent field emissions, and 2) a comparatively low fossil energy use in the mill due to the recycling of crop residues as fuel. This large contribution of the farm stage is not significantly reduced when including the refinery stage (Pleanjai and Gheewala 2009; Choo et al. 2011). However, the farm stage contribution to total fossil fuel use decreases when including the conversion of palm oil into biodiesel - this effect is also observed in the case of Jatropha oil (Ndong et al. 2009; Achten et al. 2010a; Angarita et al. 2009; Choo et al. 2011; Papong et al. 2010; Prueksakorn et al. 2010; Arvidsson et al. 2011). Focusing on the impact category of global warming, main contributors also are GHG emissions during the agricultural production and methane emissions from palm oil mill effluent treatment (POME) (Schmidt 2007; Choo et al. 2011). Nevertheless, the impacts from POME can be drastically reduced if the biogas is captured at the mill (Chuchuoy et al. 2009; Choo et al. 2011) and the contribution of the mill stage becomes even smaller if this biogas is used to fuel the mill (Chavalparit et al. 2006). Conversely field emissions dominate as soon as emissions due to land use change are included in the Life Cycle Inventory (LCI), 
especially when forests or peat lands are converted (Schmidt 2007; Reijinders and Huijbregts, 2008; Wicke et al. 2008; Zulkifli et al. 2009).

When focusing on fruits produced in temperate regions, the farm stage moreover greatly contributes to two other impact categories, fossil energy/abiotic depletion and water use (Avraamides and Fatta 2008; Beccali et al. 2009; Gazulla et al. 2010; Cappelletti et al. 2010). These two categories are partly related since the irrigated cropping systems use more energy. When looking at the cradle-to-farm-gate stages, fertiliser production and use, plant protection product use and irrigation systems consistently appear as hot-spots. An original insight is given by Avraamides and Fatta (2008) regarding the important contribution of pruning to GHG emissions (pruning in responsible for $10 \%$ of total fossil fuel use) and the main contribution of residue burning to human toxicity impact. The fate of crop residues in the life cycle of perennial cropping system would deserve more attention, considering the impacts related to both the industrial processes involved in residue management (such as pruning, composting, burning etc.) and the microbial processes involved in residue decomposing when these are landfilled or recycled for instance (Avraamides and Fatta 2008; Macedo et al. 2008). Several cradle-to-farm-gate LCA studies (Sanjuán et al. 2005; Milà i Canals et al. 2006; Mouron et al. 2006; Sim et al. 2007; Cappelletti et al. 2010) observe the influence of the variability of farming systems and of the farmers' management on the results (Mouron et al. 2006). Conclusions show that growers' techniques/ farming managements exert a considerable influence on LCA results (Milà i Canals et al. 2006), highlighting the importance of producing more specific data for agricultural productions in their context (Sanjuán et al. 2005).

\subsubsection{Methodological issues}

Several methodological issues were stressed by the authors. The first issue relates to the choice of the Life Cycle Impact Assessment (LCIA) method. LCIA methods appear to be consistent regarding global warming, which is assessed following the IPCC Tier 1 method, a linear model consistent with the LCA marginal approach at a global level. However, not all studies refer to the same version of the IPCC global warming equivalent factors. Apart from this impact category, LCIA appears to be slightly inconsistent regarding eutrophication and acidification, and severely inconsistent when assessing toxicity impacts. A sensitivity analysis on palm oil LCA (Schmidt 2007) showed that "because of the very significant differences between the results and contributors in the LCIA-methods, the results obtained for ecotoxicity are regarded as extremely uncertain and almost useless". Moreover, the ecotoxicity characterisation is highly dependent on the compartment towards which fluxes are oriented (Schmidt 2007). Results of end-point assessments vary depending on the chosen method, which jeopardises the consistency across these methods and the comparison between studies. "Normalising and weighting the characterised results using EDIP97, Impact2002+ or EcoIndicator point at different impact categories as the most significant” (Schmidt 2007). Moreover, the relevance of using European weighting and normalising factors is questionable in the case of tropical productions, which actually represent a great part of agri-food products from perennial cropping systems. Because of these methodological uncertainties, although general conclusions might not be affected, it is noted that specific result values should be considered with caution especially when comparing studies or for decision making (Yusoff and Hansen 2007).

Water consumption is hardly considered across the reviewed studies. In about one third of the reviewed studies, some figures on water consumption at agricultural or industrial stages are given but mostly without 
specifications on the used inventory methods. Across the studies on palm oil and Jatropha oil, when water use is explicitly mentioned, notably at nursery stage (Choo et al. 2011), it then contributes to energy consumption but does not appear as an impacted resource (Pleanjai and Gheewala 2009; Prueksakorn et al. 2010). Yet water use is emphasised by several authors (Sanjuán et al. 2005; Sim et al. 2007; Beccali et al. 2009; 2010) as a key aspect to be included in LCA studies and which would need further development. The need for irrigation in perennial cropping systems especially in Mediterranean countries represents a specific and new issue for LCA compared to more common LCA literature dedicated to annual crops in temperate regions. Another important methodological problem is the uncertainty attached to the modelling of toxicity impacts, sometimes used as a explanation for non-inclusion (Gazulla et al. 2010) or for exclusion from the normalised results for marine aquatic toxicity (Sim et al. 2007). Finally, the importance of including biodiversity aspects but also other dimensions of the sustainability framework such as socio-economic ones is highlighted by Sim et al. (2007). Only one detailed study on palm oil assesses the impact of land use on biodiversity (Schmidt 2007). This study reveals though that the actual methodology to assess the impact on biodiversity through the sole number of vascular plants that are prevented from existing on the studied area induces some bias. First, the methodology attributes the same weight to all vascular plant species, not allowing for a differentiation between regions with mostly uninteresting common species or with more diverse species. Moreover, the ecosystem vulnerability is determined according to each country size. Therefore small countries may be disadvantaged, whereas a same weighting factor for all regions would better emphasise the intrinsic value of biodiversity rather than a vulnerability related to spare land (Schmidt 2007).

\section{Special focus on the farm stage}

\subsection{Data origin for cropping systems}

Considering the large contribution of the farm stage to the LCIAs, it appears crucial to describe well the farming system and the subsequent data inventory. However across the studies, attention given to describing the crop management and to ensuring that data are comprehensive and representative of specific cropping systems is highly variable. Across the commodity chains, data for cropping systems often originated from diverse compiled sources. The description of farming systems was either based on data surveyed directly by the authors in small (Milà i Canals et al. 2006; Sim et al. 2007; Schmidt 2007; Angarita et al. 2009; Achten et al. 2010a; Gmünder et al. 2010) or large samples of farms (Mouron et al. 2006; Avraamides and Fatta 2008; Coltro et al. 2006; Prueksakorn and Gheewala 2008; Zulkifli et al. 2009; Pleanjai et al. 2009; Ndong et al. 2009; Papong et al. 2010; Cappelletti 2010; Choo et al. 2011), or derived from more theoretical or generic sources such as national statistics, reports, literature and expertise (Sanjuán et al. 2005; Ntiamoah and Afrane 2008; Beccali et al. 2009). In most cases, both sources of data (primary and secondary) were combined for modelling the farming system. For certain studies however, the methods and data used for the description of the farming systems were rather vague and lacked in transparency (Salomone 2003; Sanjuán et al. 2005; Beccali et al. 2009; Gazulla et al. 2010), in particular regarding agricultural machinery use, irrigation, or were completely absent (Sim et al. 2007).

Half of the reviewed studies were based only on secondary data, i.e. statistics and published literature. Data based on national statistics may be assumed to be representative of a typical cropping system in a country or a 
region. Yet no discussion on representativeness and variability was included in those reviewed papers which combined statistics and scientific literature as their main sources of data for the farm stage (Salomone 2003; Ntiamoah and Afrane 2008; Humbert et al. 2009; Busser and Jungbluth 2009). Most of the studies (80\%) did not aim at investigating a specific agricultural practice but rather at evaluating the environmental impacts of a commodity chain for a country or for a region of high production (aggregating for instance irrigated and nonirrigated area, mineral and peat soils...). As a result spatial discrepancies and temporal variability over the perennial cycle are aggregated into the median data used. However, in some more detailed papers (Coltro et al. 2006; Milà i Canals et al. 2006) a discussion on farming system diversity and representativeness was present and confirmed a wide range of agricultural practices (in terms of farm size, amounts of fertilisers and pesticides applied, etc.). Unfortunately, in most cases, data were aggregated and did not allow for enough transparency to assess suitably the detailed impact of the diverse agricultural operations. In particular, the diversity of systems surveyed is smoothed out through a compilation of an average set of single-valued parameters, rarely accompanied with indications of the range of variations (e.g. record of maximum and minimum values). This set of mean values without further statistical parameters does not allow for any assessment of the uncertainty linked to the variability of cropping systems.

\subsection{Modelling approach for perennial crops}

Most of the reviewed LCA studies (70\%) assess perennial systems in the same way as annual crops; $88 \%$ of the studies if palm oil is excluded. I.e. the inventory of farming system data is mostly based on one productive year, being the year of the investigation or the available data. Intrinsically, and without further explanation from the authors, collected data are representative for only the full productive years and do not account for the nonproductive years at the beginning of the farm stage, or for the decreasing productivity at the end of the crop cycle. Many studies did not even specify the observed or common crop cycle length (65\% of the studies if palm oil is excluded). As for annual crops, this limited data collection does not ensure a good representativeness of the LCA results due to natural, mainly climatic, variability. For perennial crops, the resulting uncertainty is further increased since their agricultural performance is also closely linked to the age of the plants, the development of rhizomes, and to phenomena such as biannual yield alternation for instance. Nevertheless, the consequences of choosing one single year for the study are generally not discussed. Some studies proposed average data collected over several inventoried years. However, in these cases only productive years were considered. Overall, attempts were made by several authors to capture the spatial or temporal variability of farms (Milà i Canals et al. 2006; Mouron et al. 2006; Sanjuán et al. 2005; Avraamides and Fatta 2008; Cappelletti et al. 2010), but more detailed considerations of the specificities of perennial cropping systems for LCA modelling and results (tree planting, growing phase, yield variability over time) were ignored in the majority of the reviewed studies. In some cases, this shortcoming is partially smoothed out for LCA studies that consider average data from large areas: It is then more likely that the geographic coverage implicitly allows for an even-age distribution of the perennial plants, including non-productive years. This expedience may be observed for crops developed on very large land areas, such as oil palm, sugarcane, or grape, with most relevance in the case of sugarcane, due to its relative short crop cycles (4-7 years), whereas for palm oil or grape the effect may be more limited due to the longer crop cycles. In any case, it is often quite unclear if and how unproductive phases are taken into account, although nursery, 
planting and immature phases may represent non negligible amounts of the water and fertilisers used over the whole cycle.

In a few studies, more attention has been paid to modelling the perennial crop cycles (Mouron et al. 2006; Schmidt 2007; Choo et al. 2011). First, these studies clearly stated the aim to include each step of the perennial cycle, or at least most of them: nursery, planting, growing phase, mature phase and end of life. Each phase then referred to a specific model and specific data, leading to an overall model which was very accurate but also very data-intensive. From this aspect, the LCA study on apple cropping systems in Switzerland by Mouron et al. (2006) provides a high level of detail, with the average productive phase based on a four-year survey of twelve productive orchards (age range from 4 to 15 years), and the inclusion of non-productive phases: tree nursing, planting and three years for orchard establishment. The end of life of the orchards though was not mentioned. Encompassing the different crop cycle phases is also applied in several LCA studies on Jatropha (Prueksakorn and Gheewala 2008; Ndong et al. 2009; Prueksakorn et al. 2010). In those cases, the authors made use of different types of data for the different phases: experimental data from the nursery to the growing phase and prospective data for the mature phase. Finally, in the case of palm oil, especially in recent years, more attention has been given to the length of the crop cycle and to a differentiation between immature and mature phases. Some studies include the nursery stage and consider averaged yields over the whole crop cycle including the immature phase (Chen 2008; Wicke et al. 2008; Zulkifli et al. 2009; Choo et al. 2011; Chuchuoy et al. 2009; Harsono et al. 2011; Hassan et al. 2011). Fewer studies also present a detailed approach of the perennial cycle with data for each year (Schmidt 2007; Achten et al. 2010b). In the study of Schmidt (2007), the perennial cycle was handled considering a theoretical even-age distribution of palm trees across a virtual plantation. Each phase of the crop cycle was accounted for, proportionally to its duration in the crop cycle length, except for nursery that was considered negligible. In this study, the inventory of each phase was consistently described and the fruit yield per hectare was explicitly adjusted to account for less productive phases.

In conclusion, across the commodity chains, very few authors proposed a methodological approach to deal with the perennial crop cycle. Instead, in the large majority of reviewed studies the problems of describing a whole perennial crop cycle are approximated by the decision to include, or not, some of the non-productive phases within the system boundary, without addressing the methodological issues of temporal and spatial representativeness of collected data. Besides, Mithraratne et al. (2008) also highlighted other important methodological issues linked to the application of LCA to perennial cropping systems notably the variability of yield and practices in the course of the plantation lifetime, due to updated government recommendations, change of owner, etc, and the potential importance of changes in soil carbon stocks in relation to greenhouse gas emissions when orchards are being established.

\subsection{Methods and data for field emissions}

In this part, we analyse the quality and comprehensiveness of the inventory of field emissions in the selected studies. The emissions of concern are the following nitrogen substances $\left(\mathrm{NH}_{3}, \mathrm{NO}_{3}{ }^{-}\right.$, and $\left.\mathrm{N}_{2} \mathrm{O}\right)$, phosphorous substances (Phosphate and Particulate $\mathrm{P}$ ), $\mathrm{CO}_{2}$ and $\mathrm{CH}_{4}$, pesticides and heavy metals. 
First of all, it is important to note that a large majority of papers give limited details on which emissions are accounted for and how, with about half of the studies providing almost no information on the methods and data used for estimating field emissions. After a thorough analysis but with some caution, it appears that the most frequently included emissions are nitrate leaching and nitrous oxide emissions to air (for about 85-90\% of the papers). The least included substances are heavy metals (25\%) and $\mathrm{NO}_{\mathrm{x}}$ (50\%). Ammonia, Phosphorous and pesticide emissions show an intermediate treatment, being quantified in about $60 \%$ of all studies. Several general guidelines for estimating field emissions in LCA are primarily cited, including the successive IPCC reports up to 2006, Audsley et al. (1997), the successive reports from the ART team (Nemecek and Kägi 2007) and several papers from Brentrup and colleagues (Brentrup et al. 2000). For pesticide emissions, the most cited reference is that of Hauschild (2000). These general guidelines themselves refer to methods and emission factors developed most of the time in other more specific studies. A few LCA studies refer directly to other LCA studies on similar products for their methods and data for estimating field emissions: Gazulla et al. (2010) is based on Milà i Canals, (2003) while Arvidsson et al. (2011) cite Schmidt (2007). Certain studies use the IPCC guidelines to estimate all the main fluxes to the environment at the field scale (Achten et al. 2010a; Ramjeawon 2004 \& 2008, Mashoko et al. 2010). Finally, a few studies only refer to punctual and disperse references picked up in the literature (Sanjuán et al. 2005; Beccali et al. 2009).

Except for the IPPC reports that contain emission factors for temperate and tropical regions, all other guidelines compile methods, equations and emission factors obtained mostly under temperate conditions and for arable crops. No discussion is generally made on the validity of using such methods for an application to perennials in tropical countries and no explanation is given on the way they were possibly adapted.

Eight studies among 39 full LCAs present a comprehensive inventory including all key field emissions as quoted above and sufficient detail on the methods used ( Milà i Canals 2003; Milà i Canals et al. 2006; Mouron et al. 2006; Avraamides and Fatta 2008; Schmidt 2007; Renouf et al. 2008, 2010; Achten et al. 2010b). These comprehensive studies correspond either to Ph.D. theses or to large projects with detailed reports available on internet (Avraamides and Fatta 2008; Achten et al. 2010b). In most Ph.D. theses, specific methodological developments are proposed on the estimation of field emissions for the studied systems. Milà i Canals (2003) proposed a refined assessment of the pesticides fractions that reach each environmental compartment by adapting the method from Hauschild (2000) to orchards in New Zealand using local research data and references. Renouf (2010) used field measurement trials and simulation modelling undertaken for Queensland sugarcane. For instance, the direct $\mathrm{N}_{2} \mathrm{O}$ emission factors used in her study are higher than the generic figure of $1.25 \%$ recommended for the national GHG inventory. This is due to field sugarcane being grown in conditions conducive of high rates of denitrification (high $\mathrm{N}$ availability, high soil moisture, high temperatures and the presence of organic matter). Schmidt (2007) proposed an approach based on a complete N and P budget adapted to a perennial crop. This budget approach allows in principle for an exhaustive inclusion of all $\mathrm{N}$ fluxes, including $\mathrm{N}$ input from legumes cultivated during the immature phase of the plantation, contribution from the organic matter decomposition from cut trees, crop residues and thinning waste. However, the references used to compile the different elements of the budget are neither all consistent nor adapted to oil palm plantations in 
Malaysia and may lead to important uncertainties on the results, especially for those elements such as nitrate leaching, which are estimated by difference between $\mathrm{N}$ inputs and $\mathrm{N}$ outputs.

The inclusion of emissions linked to land use and land use change (LULUC) is almost absent from the LCA studies analysed here, except for palm oil and in a few studies focused on carbon footprint (Schmidt 2007; Page et al. 2011; Siangjaeo et al. 2011). The potential importance of including soil carbon change in the GHG emissions in relation to the establishment of the orchards was also highlighted by Mithraratne et al. (2008) in their report on the carbon footprinting for the kiwifruit supply chain (from permanent pasture to a kiwifruit orchard). In the case of palm oil, as for any crop that may be grown after tropical forest land clearing, it was shown that emissions due to land use change may contribute to a great extent to field emissions and overall global warming impact (Germer and Sauerborn 2008; Wicke et al. 2008; Harsono et al. 2011). Recent studies notably considered the amount of $\mathrm{CO}_{2}$ emissions due to direct land use change, and more specifically due to the loss of $\mathrm{CO}_{2}$ from soil when planting oil palm trees on peat soils (very high organic matter content) (Schmidt 2007; Wicke et al. 2008; Lam et al. 2009; Yee et al. 2009). However, emissions due to land use and land use change were not always included in the assessment for mainly two reasons. First, national average-based LCAs for palm oil aimed to assess the potential impact of current plantation in countries where oil palm already is in third or fourth generation. In these countries, Malaysia or Indonesia for instance, oil palm cultivation was considered to follow oil palm and the land use is either not considered or only qualitatively assessed within scenarios for plantation expansion (Yusoff and Hansen 2007; Choo et al. 2011). The second reason lies in the lack of international consensus on key parameters especially for perennial cropping systems. These parameters concern 1) the carbon stocks of different land uses and cropping systems, and 2) the time period for the amortisation of field emissions due to land use change, which strongly impacts the greenhouse gas balance (Wicke et al. 2008). As mentioned earlier, different approaches can be used to assess LULUC impacts, either the IPCC guidelines (2006), carbon debt (Gibbs et al. 2008), or other methods (Henson 2004; Achten et al. 2010b; Milà i Canals et al. 2012). Objectives and precisions of these methods are highly variable. None of the reviewed studies thoroughly assessed all potential field emissions linked to LULUC.

Overall, it is difficult to evaluate the quality and completeness of the inventory of field emissions in the reviewed studies. However, one can note that almost all studies correspond to measurements or parameterised equations obtained for annual crops in temperate regions. The possible influence on field emissions of the key characteristics of perennial crops in general such as their spatial structure (with rows and inter-rows), the nutrient recycling efficiency through rhizomes or highly developed root systems, or the use of irrigation, notably in Southern regions, are disregarded. Therefore more research is needed to verify the quality and comprehensiveness of field emissions assessments, since the farm stage of food and energy crops is a major contributor to several impact categories. The issue of the carbon cycle for perennials is also specific and generally omitted from the analysis, as well as emissions due to land use change which can have a critical importance for certain tropical crops, e.g. those expanding on peat land or forest land.

\section{Main challenges and recommendations}

\subsection{Integrating the perennial crop cycle within LCA}


Cultivation of perennials differs from that of annuals in several aspects which may drastically influence the environmental impacts and their estimation. For a decade or so, LCA methodology has been adapted for agricultural products to account better for site dependency and agricultural practices, intrinsically focusing on annual crops. Accuracy in encompassing the spatial and temporal scopes of perennials will depend on both the objectives of the study and the data availability. Given the duration of perennial cropping systems, it is not easy and sometimes even impossible to gather data for the whole cropping cycle. Either technical data have not been recorded since the planting of the perennials, or the plantation is too young to reflect all the production stages, such as the decline in crop yield at the end of the cycle. Finally, the availability of data for various stages will also depend on the structure and size of the plantation. Small scale plantations ( $<10$ hectares) are usually managed by farmers who are likely to conduct their first generation plantation without any prospective view on the whole crop cycle. Conversely, large scale industrial plantations consist more often of several plantation blocks of different ages, among which some may be already in second or later generation of production, i.e. after felling and re-planting. We suggest that every stage of the perennial cropping cycle should be encompassed. Where primary data are not available, secondary data should be used instead. We particularly emphasise that i) nursery stage should be included in LCA, although its relative contribution may be negligible (Schmidt, 2007; Choo et al. 2011), and ii) using an average yield that does not account for unproductive stage (immature phase) or for any decline in production at the end of the cycle should be considered as a last resort. We first argue that nursery is a fundamental input to the plantation (Cerutti et al. 2011). The contribution of the nursery stage to total impacts may be limited depending on the planting density and the duration of the cropping cycles, but for the purpose of comparability between perennials, nursery stage should be included. Moreover, the quality of seedlings and hence the nursery management predetermine the productivity of the plantation over the whole cycle (Cochard et al. 2001; Harsono et al. 2011). Some impact categories may be more important at nursery stage, although the total contribution of nursery stage remains limited due to the high productivity of nursery per hectare. It is notably the case of pumped water consumption per tree during oil palm nursery stage in countries where plantations are not irrigated such as Indonesia for instance. For some other perennials, nursery stage and planting material have a tremendous impact on the implementation costs, so that the economic decision can become a key factor and should be combined with environmental considerations (e.g. Miscanthus rhizome: Jorgensen and Mortensen 1997; Lewandowski 1998). Finally, where data on nursery stage are not available a fraction of field production impacts can be used as a proxy considering the theoretical duration and plant capacity of nursery.

We here propose a methodological framework to account better for the duration of perennial cropping systems and its implications in terms of spatial and temporal scopes. We defined three approaches to model the perennial crop cycle: a) spatial, b) modular, and c) chronological assessments. In the spatial assessment, the perennial system is captured from an area representative of the whole cycle. In the modular assessment, each stage is modelled independently. The chronological assessment consists in describing the whole cycle following the historical course of the crop development. The choice between these approaches will depend on the study objectives and the data availability. Figure 1 proposes a decision tree to choose the most appropriate approach. 
The pathways by default, i.e. where data are missing, mostly lead to a modular assessment which can be considered as the minimum requirement to account for the perennial cropping cycle. In other cases, more sophisticated approaches could be used and should be justified according to the study objectives. On the other hand, when assessing the impacts of management changes occurring at one stage of the crop cycle, the LCA may be focused on just one stage for comparison purposes provided that i) it can be proven that changes at this stage do not have repercussions on the other stages, and that ii) it is clearly stated that it is not the perennial crop product but the management practice for one particular stage that is under scrutiny.

\subsection{Improving the methods and data quality for field emissions}

Field emissions are subject to an intrinsic large uncertainty due to their high variability in space and time. Operational models such as IPCC Tier 1 only provide a rough estimate of these emissions based on a range of data that only cover part of this variability. Hence these statistical models are merely indicative for conditions which were not represented in the used data sets. It is particularly true for perennial and tropical cropping systems. Despite an exhaustive data collection of $\mathrm{N}_{2} \mathrm{O}$ and $\mathrm{NO}_{\mathrm{x}}$ field emissions all over the world (1978-2004) that was carried out to reduce the uncertainty in the statistical model used in IPCC Tier 1, sub-tropical and tropical systems remain clearly underrepresented (Bouwman et al. 2002; Stehfest and Bouwman 2006). Moreover, although "crop type" appeared to be a controlling factor of $\mathrm{N}_{2} \mathrm{O}$ emissions in agricultural field, no "crop type" for perennial crops could be identified and assessed. If perennial crops were represented, they were considered together with "Other crops" besides "Grass” or "Wetland rice” (Stehfest and Bouwman 2006). As in this example, other operational models such as SALCA-N (Richner et al. 2006) or SALCA-P (Prasuhn 2006) used by Ecoinvent to estimate field emissions of reactive nitrogen or phosphorus, are lacking representative data for perennial crops and tropical regions for their calibration. Research is therefore needed to produce data sets on perennial cropping systems and their field emissions in order to account better for perennial crops in existing operational models.

In the same vein, specific development of process-based models for perennial cropping systems could allow for more accuracy in estimating field emissions. For at least thirty years, process-based models have largely been developed, which account for both local conditions and agricultural management, and estimate both yields and polluting emissions to the environment. For agricultural LCAs, such models can help compile inventory data that are consistent with the local environmental conditions and agricultural management. Nevertheless, up to now only few process-based models have been specifically developed for perennial agro-ecosystems (OPRODSIM by Henson 2005; ALMANAC by Kiniry et al. 2005; MISCANFOR by Hastings et al. 2009). In particular, the mechanistic approach for crop growth modelling relies on parameters such as light interception, photosynthesis type and the response of plant development to temperature, weighted by nitrogen or water stress indices. Re-mobilisation of nutrients within the plant especially towards and from rhizomes for some perennials is still not commonly modelled, notably due to numerous experimental constraints when aiming to characterise the development and functioning of rhizomes.

As long as models, process-based or operational ones, are not calibrated for a given crop and the local conditions of the cropping system, the only option to improve data quality in LCIs remains the collection of representative 
and detailed primary data. Field measurements may be also relevant especially for critical variables, e.g. biomass stock, field emissions etc. The sampling size and its spatial and temporal representativeness should be stated. Data sets should describe the functioning of the agro-ecosystem as much as possible and cover several years, if not the whole cycle, to account for at least part of the natural seasonal variability. ISO norms already contain specific requirements in terms of data quality, but most reviewed LCAs did not provide information regarding the quality of data used. It should be here emphasised that information on the statistical relevance of data used to represent the temporal and spatial functioning of the cropping cycle is paramount to assess the uncertainty linked to the modelling of the perennial cropping system.

\subsection{Taking into account the impact of land use and land-use changes (LULUC)}

In recent years, integrating LULUC into LCA has been an increasing issue for agricultural-based product assessments (Searchinger et al. 2008, Fargione et al. 2008; Reinhardt and von Falkenstein 2011; Milà I Canals et al. 2012) and an important field of research for LCA methodology (Lindeijer 2000; Weidema 2001; Milà i Canals et al. 2007; Müller-Wenk and Brandão 2010; Brandão et al. 2011). Due to long growth cycles, perennial crops are very distinct from annual crops in terms of potential impacts related to land occupation and land use change. Despite the recent focus on LULUC and the particularities for perennial crops in that matter, only a few of the reviewed papers attempted to address specifically this issue in LCAs of perennial crops (Schmidt 2007; Wicke et al. 2008; Achten et al. 2010b; Siangjaeo et al. 2011). It could be due to both a lack of clear consensual methods to account for LULUC in LCA and a lack of data and knowledge to model comprehensively the impacts.

In terms of land use, LCA methodological developments have focused on accounting for the impacts of land management on biodiversity and soil quality, i.e. on the maintaining of soil function potentials. Commonly studied impact mechanisms include land use effects on species diversity (Koellner and Scholz 2008), soil erosion, soil organic matter changes, soil tillage and soil carbon stocks. Difficulties in appraising these mechanisms and quantifying the impacts to be modelled in LCA are due first, to the intrinsic complexity of soil and involved processes (physical and biological interactions, antagonist or reversible dynamics, varying timeframes etc.), and second, to a consequent lack of harmonisation of the parameters to be assessed (soil type, soil depth, soil resilience etc.). In these matters, the lack of fundamental understanding of processes and the lack of data are particularly severe in the case of perennial crops compared to annual crops or grasslands. Large research efforts are needed to assess, quantify and model the impacts of agricultural management on perennial stands and soils in perennial cropping systems. In particular, emphasis should be put on characterising the biomass stands (above- and belowground) and the dynamics of soil cover and organic matter pools in relation with agricultural management, e.g. organic fertilisation, pruning, reduced soil tillage or patterns of pesticide application. When field data are not available, biomass stocks and stock durations should be quantified according to IPCC guidelines and upcoming ISO 14067. Such generic data do not cover the high diversity of perennial cropping systems and may be not relevant for a specific crop and a given management. However, information is still missing on important factors for perennials such as the root biomass, or the impact of management on biomass degradation and soil organic carbon under long-term stands. Field experiments and 
modeling works are highly needed in order to develop a robust framework for carbon cycle modeling in LCAs of perennial crops.

In terms of land use change, issues in assessing the impacts in LCA are double: i) identifying the potential direct and indirect land use changes, and ii) quantifying the associated transformation impacts. Both issues mean to deal with specific challenges:

i) Difficulties related to the identification of LUC depend on the type of LUC. For direct LUC, they are mainly technical and depend primarily on the availability of long-term data sets. When available, precise sitedependent databases or from historical GIS records may help identify LUC but the GIS resolution may be limiting especially in the case of small-scale planting or agro-forestry systems. Otherwise, some approximation can be done by comparing increased land areas under the studied crops and decreased land areas under relevant land use types (Milà i Canals et al. 2012). This method is however not relevant for agroforestry systems or shifting cultivation. In the case of indirect LUC, the identification must be based on a multi-disciplinary modelling of global land uses (Schmidt 2007; Kloverpris et al. 2008), including market analysis and price consideration, which can be highly volatile.

ii) The quantification of LUC impacts suffers from a lack of both consensual methodological framework and accurate data, especially for perennial cropping systems (see paragraph about land use). Despite intensive research work and improvement of methodological frameworks (IPCC 2006; PAS2050 ${ }^{4}$; ISO $14067^{5}$; $\mathrm{ILCD}^{6}$ ), doubts subsist on the scientific and geopolitical justification of some key parameters such as the timeframe for carbon storage, amortisation for carbon release or other methods of accounting for time preference (Fearnside 2002; Müller-Wenk and Brandão 2010).

Finally, issues related to LULUC in LCA are exacerbated in the case of tropical crops such as palm oil or sugarcane for instance. Indeed, impacts of LUC may be particularly severe in tropical regions where natural vegetation is still dominant but fast decreasing due to the pressure of both industrial and agricultural developments. Tropical natural vegetation stands represent hot spots of both biodiversity and carbon stocks (Laumonier et al. 2010; Barlow et al. 2007). Some of these stands are also found on peatlands, whose drainage for agricultural purpose can have drastic impacts on soil carbon losses and greenhouse gas emissions or increased susceptibility to fire (Wetlands International 2010). Moreover, LUC may induce slash and burn practices, whose impacts may be still not fully addressed and quantified in LCA. Last but not least, perennial crops in the tropics are commonly associated with other crops in agroforestry systems. In these cases, assessing

\footnotetext{
${ }^{4}$ PAS2050 by BSI (2011) Specification for the assessment of the life cycle greenhouse gas emissions of goods and services by The British Standards Institution. 45 p.

${ }^{5}$ Currently developed by the ISO

${ }^{6}$ ILCD developed by the European Commission-Joint Research Centre - Institute for Environment and Sustainability (2011) International Reference Life Cycle Data System (ILCD) Handbook- Recommendations for Life Cycle Impact Assessment in the European context. First edition November 2011. EUR 24571 EN. Luxemburg. Publications Office of the European Union; 2011. 159p.
} 
the land use impacts related to all crops or to one taken separately may require specific research and methodological developments.

\subsection{Specific challenges for agroforestry systems}

Some perennial crops, for instance coffee and cocoa, are cultivated in association with one or more other plants, such as nitrogen-fixing plants (e.g. Inga densiflora), fruit-bearing trees (e.g. banana), or annual crops (e.g. cassava). For some other perennials, such as oil palm, crop mixing is also widely used to generate income in the first years of the plantation (Malézieux et al. 2009). The existence of trees with crops defines an agroforestry system (Malézieux et al. 2009). Multispecies systems, such as agroforestry systems, tend to be presented as more sustainable than mono-specific cropping systems for a range of reasons including, i) biodiversity preservation and consequent greater resilience, ii) reduced use of fertilisers due to increased nutrient recycling and nutrientuse efficiency, iii) soil conservation and water quality thanks to increased soil cover and reduced runoff, iv) income stability due to diverse income sources and lower dependence on external inputs and product prices, etc. (Malézieux et al. 2009). In counterpoint to these claims, some scientific publications report lower yields of the main crop due to resource competition (Siles et al. 2010), which the income from the secondary crop may not compensate and which may lead to plantation expansion, with a risk of further encroaching on primary forest; and higher emissions of $\mathrm{N}_{2} \mathrm{O}$ from nitrogen-fixing plants, when compared with a single crop system using inorganic fertiliser (Harmand et al. 2007; Hergoualc’h et al. 2008). Hence, advantages of multispecies systems should not be over-generalised and further studies are needed to understand clearly the mechanisms governing beneficial effects of multispecies systems and better assess the potential ecological services that these systems may provide (Malézieux et al. 2009).

From a methodological point of view, such agroforestry systems raise the question of impact allocations between associated crops. Several issues need to be taken into account in this respect. First, agroforestry systems are highly diversified so that different approaches and methods may be needed. In this regard, three interconnected dimensions need to be considered. The first dimension is the spatial arrangement of the crops, both in vertical and horizontal directions. The second dimension is the timing of crop developments, which is correlated to the spatial dimension. The last one is the functional dimension of the diverse crops, i.e. cultivated for their products or as providers of specific functions such as shade or N-fixation. In traditional LCA, time and space are hardly accounted for, whereas the system function is the basis for the calculation. LCA of agroforestry systems should therefore seek a comprehensive description and quantification of costs and services of all crops within the system. The second issue relates to identifying and quantifying all services of an agroforestry system is a complex matter especially due to collective dynamics that may lead to emergent properties that cannot be deduced from species properties alone (Malézieux et al. 2009). Finally, due to these interactions between crops it might be virtually impossible to allocate costs and services to the diverse crops only based on objective measurements.

Within this context, in a first attempt, we suggested to adopt two different approaches depending on the system complexity and data availability. In the case of simply structured systems, such as sequential or row agroforestry (Table I. In Malézieux et al. 2009), performances and impacts could be quantified for each crop individually, based on corresponding crop performances and impacts assessed in single-crop systems. To this end, input and 
output flows to the pure-stand cropping system would be multiplied by the inverse of the Land Equivalent Ratio (LER, Mead and Willey 1980 p/51 In. Malézieux et al. 2009). This ratio indicates the amount of land needed to grow two species together instead of as pure stands while reaching the same yields. For LER=1, inter- and intraspecific interactions are equivalent; for LER $<1$ mixed systems show a yield disadvantage; and for LER $>1$ mixed systems show a yield advantage (Malézieux et al. 2009). This approach, based on the yield function, may be applied when data on pure-stand cropping systems and yields of mixed system are available and may be particularly interesting to get a first insight into a mixed system advantages and impacts.

In the case of complex agroforestry systems (Table I In Malézieux et al. 2009), a more data-intensive approach will be necessary whatever the chosen system boundary and functional units. Depending on the goal and scope of the study, a surface-based functional unit (e.g. 1 ha) may be chosen and help discriminate several option for land uses while accounting for the environmental service of crop associations. It might however not be sufficient when comparing agroforestry systems or looking for optimisation strategies to enhance services provided by specific crops or reduce specific impacts. In this last case, detailed data will be needed to characterise both the mixed cropping systems (patterns of fertiliser and pesticide applications, yield distributions in space and time, etc.) and identify the diversity of services provided and input/output flows related to each crop. Participatory methods might be a good option for both service identification and classification according to local people's priorities in order to orient allocation choices (Cardoso et al. 2001; Jagoret 2011). Weight and economic allocations may be used, with economic allocations possibly more relevant in most cases, due to the usually large differences in economic value between the primary and secondary crops, e.g. coffee beans for exportation associated with bananas for local consumption. Beyond weight and economic allocations, the value of the secondary crop for food security of the farming community may also be relevant for inclusion in the allocation method. If a unique functional unit is not relevant for all mixed crops, potentially leading to an inconsistent allocation of burdens, a final option may also be to consider several functions provided by the agroforestry system and calculate a vector of life-cycle impact scores per impact category depending on the functional units chosen.

Among the LCAs reviewed in the present paper, no crop association system was modeled. The directions suggested in this paper for developing LCA of agroforestry systems must be tested against data availability and methodological bottlenecks. A large research effort is potentially still needed to succeed in applying LCA methodology to agroforestry systems.

\section{Conclusions}

This review was based on a large number of studies covering a wide range of perennial crops all over the world. There was a great heterogeneity across these studies in terms of goal and scope, methodological choices and data sources especially concerning the farm stage. Apart from a very few detailed studies, mostly Ph.D. theses, very little attention was paid to take into account the agronomical specificities of perennial cropping systems within the LCA. It may be due to both a lack of focus on the farm stage, given the goal and scope of the studies or the lack of data and appropriate models, and a lack of methodological guidelines to account for the whole perennial cycles and agricultural specificities. 
A general methodological framework was proposed to account for the whole lifespan of the perennial crop within LCA. This framework should help harmonise calculations among perennial crop LCAs and allow for a sounder comparison with annual crops. Nevertheless, further research works as well as methodological developments are still needed to keep on improving LCAs of agricultural and perennial crop products:

- To produce data sets on perennial cropping systems, including detailed inventories of agricultural management at each stage (nursery to senescence) and subsequent field emissions (with field measurements where possible). These data sets should help increase the representation of perennials and the robustness of statistical models. Emphasis should be also put on describing agroforestry systems and the multiple services they may provide;

- To work on methodological developments to assess the life cycle impacts of agroforestry systems within LCA;

- To develop mechanistic models to account better for biogeochemical specificities within perennial agro-ecosystems, both in temperate and tropical regions (e.g. mechanistic models that could better simulate nitrification and denitrification, mineralisation and other microbiological processes together with the dynamics of perennating organs and re-mobilisation mechanisms);

- $\quad$ To focus on tropical cropping systems, whose high diversity contrasts with the low rate of data available, should the data sets not exist or not be published.

\section{Acknowledgments}

The authors, members of the ELSA group (Environmental Life-cycle and Sustainability Assessment www.elsa-lca.org), thank the French Region Languedoc-Roussillon for its support to ELSA. The authors are very grateful to Dr. Eric Malézieux for his valuable comments. We finally want to warmly thank the anonymous reviewers for their comments which improved the quality of the paper.

\section{References}

Achten WMJ, Almeida J, Fobelets V, Bolle E, Mathijs E, et al. (2010a) Life cycle assessment of Jatropha biodiesel as transportation fuel in rural India. Appl Energ 87: 3652-3660

Achten WMJ, Vandenbempt P, Almeida J, Mathijs E, Muys B (2010b) Life Cycle Assessment of a Palm Oil System with Simultaneous Production of Biodiesel and Cooking Oil in Cameroon. Environ Sci Technol 44:4809-4815

ADEME (2010) Analyses de Cycle de Vie appliquées aux biocarburants de première génération consommés en France. Etude réalisée pour le compte de l'ADEME, du MEEDDM, MAAP, et de France Agrimer par BIO Intelligence Service, 236 p.

Almeida J, Achten WMJ, Duarte MP, Mendes B, Muys B (2011): Benchmarking the environmental performance of the Jatropha biodiesel system through a generic Life Cycle Assessment. Environ Sci Techno 45: 54475453 
Angarita EEY, Lora EES, da Costa RE, Torres EA (2009) The energy balance in the Palm Oil-Derived Methyl Ester (PME) life cycle for the cases in Brazil and Colombia. Renew Energ 34:2905-2913

Aranda A, Scarpellini S, Zabalza I (2005) Economic and environmental analysis of the wine bottle production in Spain by means of life cycle assessment. Int J Agr Resour Govern Ecol 4(2):178-191

Ardente F, Beccali G, Cellura M, Marvuglia A (2006) POEMS: A Case Study of an Italian Wine-Producing Firm. Environ Manage 38:350-364

Arvidsson R, Persson S, Fröling M, Svanström M (2011) Life cycle assessment of hydrotreated vegetable oil from rape, oil palm and Jatropha. J Cleaner Prod 19:129-137

Audsley E (Coord.), Alber S, Clift R, Cowell S, Crettaz P, Gaillard G, et al. (1997) Harmonisation of Environmental Life Cycle Assessment for Agriculture. Final Report. Concerted Action AIR3-CT94-2028. European Commission. DG VI Agriculture. SRI, Silsoe, UK.

Avraamides M, Fatta D (2008) Resource consumption and emissions from olive oil production: a life cycle inventory case study in Cyprus. J Cleaner Prod 16:809-821

Barlow J, Gardner T, Araujo I, Avila-Pires T, Bonaldo A, et al. (2007) Quantifying the biodiversity value of tropical primary, secondary, and plantation forests. PNAS 104:18555-18560.

Basset-Mens C, Anibar L, Durand P, van der Werf HMG (2006) Spatialised fate factors for nitrate in catchments: Modelling approach and implication for LCA results. Sci Total Environ 367:367-382

Beccali M, Cellura M, Iudicello M, Mistretta M (2009) Resource Consumption and Environmental Impacts of the Agrofood Sector: Life Cycle Assessment of Italian Citrus-Based Products. Environ Manage 43:707724

Beccali M, Cellura M, Iudicello M, Mistretta M (2010) Life cycle assessment of Italian citrus-based products. Sensitivity analysis and improvement scenarios. J Environ Manage 91:1415-1428

Bessou C, Lehuger S, Gabrielle B, Mary B (2012) Using a crop model to account for the effects of local factors on the LCA of sugar beet ethanol in Picardy region, France. Int J Life Cycle Assess. Online Doi: 10.1007/s11367-012-0457-0

Bonneau X (1998) Recherche sur les facteurs limitant la production végétale en conditions de stress hydrique. Cas du cocotier à Gunung Batin (Indonésie) : rôles du chlore dans l'économie de l'eau. Ph.D. Dissertation, AgroParisTech, Paris. 196p.

Botha T, von Blottnitz H (2006) A comparison of the environmental benefits of bagasse-derived electricity and fuel ethanol on a life-cycle basis. Energ Policy 34: 2654-2661

Bouwman AF, Boumans LJM, Batjes NH (2002) Emissions of $\mathrm{N}_{2} \mathrm{O}$ and NO from fertilized fields: Summary of available measurement data. Global Biogeochem Cycles 16:1058

Brandão M, Milà I Canals L (2012) Global characterisation factors to assess land use impacts on biotic production. Int J Life Cycle Assess. doi:10.1007/s11367-012-0381-3

Brandão M, Milà i Canals L, Clift R (2011) Soil organic carbon changes in the cultivation of energy crops: Implications for GHG balances and soil quality for use in LCA. Biomass Bioenerg 35:2323-2336

Brentrup F, Küsters J, Lammel J, Kuhlmann H (2000) Methods to estimate on-field nitrogen emissions from crop production as an input to LCA studies in the agricultural sector. Int J Life Cycle Assess 5:349-357 
Busser S, Jungbluth N (2009a). The role of flexible packaging in the life cycle of coffee and butter. Int J Life Cycle Assess 14(1):80-91

Busser S, Jungbluth N (2009b) LCA of Chocolate Packed in Aluminium Foil Based Packaging. ESU-services GmbH executive summary report for the German Aluminium Association (GDA)

Cappelletti GM, Nicoletti GM, Russo C (2010) Life Cycle Assessment (Lca) of Spanish-Style Green Table Olives. Ital J Food Sci 22:3-14

Cardoso I. Guijt I, Franco F. Carvalho A, Ferreira Neto P (2001) Continual learning for agroforestry system design: university, NGO and farmer partnership in Minas Gerais, Brazil. Agr Syst 69:235-257

Cerutti AK, Bruun S, Beccaro GL, Bounous G (2011) A review of studies applying environmental impact assessment methods on fruit production systems. J Environ Manage 92:2277-2286

Chavalparit O, Rulkens Wh, Mol Apj, Khaodhair S (2006) Options for Environmental Sustainability of the Crude Palm Oil Industry in Thailand through Enhancement of Industrial Ecosystems. Environ Dev Sustain 8:271-287

Chen SS (2008) The LCA Approach to Illustrate Palm Oil's Sustainability Advantage. Proceedings of Int'l Palm Oil Sustainability Conference, Kota Kinabalu, Sabah. p 11

Choo YM, Muhamad H, Hashim Z, Subramaniam V, Puah CW, et al. (2011) Determination of GHG contributions by subsystems in the oil palm supply chain using the LCA approach. Int J Life Cycle Assess 16:669-681

Chuchuoy K, Paengjuntuek W, Usubharatana P, Phungrassami H (2009) Preliminary Study of Thailand Carbon Reduction Label: A Case Study of Crude Palm Oil Production. Eur J Sci Res 34:252-259

Cochard B, Adon B, Kouame R, Durand-Gasselin T, Amblard P (2001) Advantages of improved commercial palm oil (Elaeis guinensis Jacq.) seeds. OCL-Ol Corps Gras Lipides 8:654-658

Coltro L, Mourad AL, Oliveira PAPLV, Baddini JPOA, Kletecke RM (2006). Environmental profile of Brazilian green coffee. Int J Life Cycle Assess 11(1): 16-21

Coltro L, Mourad AL, Kletecke RM, Mendonça TA, Germer SPM (2009) Assessing the environmental profile of orange production in Brazil. Int J Life Cycle Assess 14:656-664

Contreras AM, Rosa E, Pérez M, Van Langenhove H, Dewulf J (2009) Comparative Life Cycle Assessment of four alternatives for using by-products of cane sugar production. J Cleaner Prod 17: 772-779

da Costa RE, Lora EE., Angarita EY, Torres E (2006) The energy balance in the production of palm oil biodiesel two case studies: Brazil and Colombia. Proceedings, World Bioenergy

de Monte M, Padoano E, Pozzetto D (2005) Alternative coffee packaging: an analysis from a life cycle point of view. J Food Eng 66:405-411

de Souza SP, Pacca S, de Ávila MT, Borges JLB (2010) Greenhouse gas emissions and energy balance of palm oil biofuel. Renew Energ 35:2552-2561

Diers A, Langowski H-C, Pannkoke K, Hop R (1999). Produkt-Ökobilanzvakuumverpackter Röstkaffee. Fraunhofer-Institut für Verfahrenstechnik und Verpackung, 214pp.

EPA (1995). Food and agricultural industries, compilation of air pollutant emission factors, volume I (AP42). U.S.Environmental Protection Agency 
Fargione J, Hill J, Tilman D, Polasky S, Hawthorne P (2008) Land Clearing and the Biofuel Carbon Debt. Science 319:1235 -1238

Farrell AE, Plevin RJ, Turner BT, Jones AD, O’Hare M, et al. (2006) Ethanol Can Contribute to Energy and Environmental Goals. Science 311: 506 -508

Fearnside PM (2002) Time preference in global warming calculations: a proposal for a unified index. Ecol Econ 41(1): 21-31

Flysjo A, Ohlsson T (2006). Life cycle assessment (LCA) of different Central American agro-food chains. Swedish Institute for Food and Biotechnology (SIK) report Nr 752 2006. ISBN 91-7290-252-3

Gazulla C, Raugei M, Fullana-i-Palmer P (2010) Taking a life cycle look at crianza wine production in Spain: where are the bottlenecks? Int J Life Cycle Assess 15:330-337

Germer J, Sauerborn J (2008) Estimation of the impact of oil palm plantation establishment on greenhouse gas balance. Environ Dev Sustain 10:697-716

Gibbs HK, Johnston M, Foley JA, Holloway T, Monfreda C, et al. (2008) Carbon payback times for crop-based biofuel expansion in the tropics: the effects of changing yield and technology. Environ Res Lett 3:034001

Gmünder SM, Zah R, Bhatacharjee S, Classen M, Mukherjee P, et al. (2010) Life cycle assessment of village electrification based on straight jatropha oil in Chhattisgarh, India. Biomass Bioenerg 34: 347-355

Graefe S, Dufour D, Giraldo A, Muñoz LA, Mora P, et al. (2011) Energy and carbon footprints of ethanol production using banana and cooking banana discard: A case study from Costa Rica and Ecuador. Biomass Bioenerg 35:2640-2649

Groot WJ, Borén T (2010): Life cycle assessment of the manufacture of lactide and PLA biopolymers from sugarcane in Thailand. Int J LCA 15: 970-984

Guinée J, Gorrée M, Heijungs R, Huppes G, Kleijn R, et al. (Eds.) (2001) Life Cycle Assessment. An Operational Guide to the ISO Standards. VROM and CML, Leiden University, The Netherlands.

Hanssen OJ, Rukke EO, Saugen B, Kolstad J, Hafrom P, et al. (2007) The Environmental Effectiveness of the Beverage Sector in Norway in a Factor 10 Perspective. Int J Life Cycle Assess 12(4):257-265

Härdter R, Fairhurst TH (2003) Oil Palm: Management for Large and Sustainable Yields. Publishers: Potash \& Phosphate Institute (PPI)/Potash \& Phosphate Institute of Canada (PPIC) and International Potash Institute (IPI). ISBN 981-04-8485-2. 396p.

Harmand M, Avila H, Dambrine E, Skiba U, De Miguel S, et al. (2007) Nitrogen dynamics and soil nitrate retention in a Coffea arabica - Eucalyptus deglupta agroforestry system in Southern Costa Rica. Biogeochemistry 85(2):125-139

Harsono SS, Prochnow A, Grundmann P, Hansen A, Hallmann C (2011) Energy balances and greenhouse gas emissions of palm oil biodiesel in Indonesia. GCB Bioenergy, doi: 10.1111/j.1757-1707.2011.01118.x

Hassan MNA, Jaramillo P, Griffin WM (2011) Life cycle GHG emissions from Malaysian oil palm bioenergy development: The impact on transportation sector’s energy security. Energ Policy 39:2615-2625

Hastings A, Clifton-Brown J, Wattenbach M, Mitchell CP, Smith P (2009) The development of MISCANFOR, a new Miscanthus crop growth model: towards more robust yield predictions under different climatic and soil conditions, Glob Change Biol Bioenerg 1(2):154-170 
Hauschild MZ (2000) Estimating pesticide emissions for LCA of agricultural products. In: Weidema BP, Meeusen MJG (Eds.), Agricultural Data for Life Cycle Assessments, vol. 2. LCANet Food, The Hague, The Netherlands, pp. 64-79.

Henson I.E. (2004) Modelling Carbon Sequestration and Emissions Related to Oil Palm Cultivation and Associated Land Use Change in Malaysia. MPOB Technology, Kajang, Malaysia.

Henson I.E. (2005) OPRODSIM, a versatile, mechanistic simulation model of oil palm dry matter production and yield. In: Proceedings of PIPOC 2005 International Palm Oil Congress, Agriculture, Biotechnology and Sustainability Conference, 801-832. Kuala Lumpur: Malaysian Palm Oil Board.

Hergoualc’h K, Skiba U, Harmand JM, Hénault C (2008). Fluxes of greenhouse gases from Andosols under coffee in monoculture or shaded by Inga densiflora in Costa Rica. Biogeochemistry 89:329-345.

Hirsinger F, Schick KP, Stalmans M (1995) A Life-Cycle Inventory for the Production of Oleochemical Raw Materials. Tenside Surf Det 5: 420-432

Hou J, Zhang P, Yuan X, Zheng Y (2011): Life cycle assessment of biodiesel from soybean, jatropha and microalgae in China conditions. Renew Sust Energ Rev 15: 5081-5091

Humbert S, Loerincik Y, Rossi V, Margni M, Jolliet O (2009). Life cycle assessment of spray dried soluble coffee and comparison with alternatives (drip filter and capsule espresso). J Cleaner Prod 17(15):13511358

IPCC (2006) IPCC Guidelines for National Greenhouse Gas Inventories, Prepared by the National Greenhouse Gas Inventories Programme, Eggleston HS, Buendia L, Miwa K, Ngara T and Tanabe K (eds). Published: IGES, Japan.

Jagoret P, Michel-Dounias I, Malézieux E (2011) Long-term dynamics of cocoa agroforests: a case study in central Cameroon. Agroforest Syst 81:267-278

Jolliet O, Saadé M, Crettaz P, Skaked S (2005) Analyse du cycle de vie: comprendre et réaliser un écobilan. PPUR presses polytechniques. 242p.

Jorgensen U, Mortensen J (1997) Perennial crops for fibre and energy use as a tool for fulfilling the Danish strategies on improving surface and ground water quality. SP Rapport - Statens Planteavlsforsog 12-21

JRC, EUCAR, CONCAWE (2008) Well-to-Wheels study. Version 3, year 2008. http://ies.jrc.ec.europa.eu/ouractivities/ support-to-eu-policies/well-to-wheels-analysis/WTW.html

Ju LP, Chen B (2011) Embodied energy and emergy evaluation of a typical biodiesel production chain in China. Ecol Model 222(14): 2385-2392

Kiniry JR, Cassida KA, Hussey MA, Muir JP, Ocumpaugh WR et al. (2005) Switchgrass simulation by the ALMANAC model at diverse sites in the southern US. Biomass Bioenerg 29:419-425.

Kløverpris J, Wenzel H, Nielsen PH (2008) Life Cycle Inventory modelling of land use induced by crop consumption - Part 1: Conceptual analysis and methodological proposal. Int J Life Cycle Assess 13(1):13-21

Koch P, Gaillard G, Van der Werf HM, Salou T, Basset-Mens C, et al. (2011) Methodological guidelines for LCA of French agricultural products. LCAfood conference 2010, Bari, Italy

Koch S (2003) LCA of Biodiesel in Costa Rica. An environmental study on the manufacturing and use of palm oil methyl ester. Project Report. University of Applied Sciences Northwestern Switzerland. 56p. 
Koellner T, Scholz RW (2008): Assessment of land use impacts on the natural environment - Part 2: Generic characterization factors for local species diversity in Central Europe. Int J Life Cycle Assess 13(1):32-48.

Lam MK, Lee KT, Mohamed AR (2009) Life cycle assessment for the production of biodiesel: A case study in Malaysia for palm oil versus Jatropha oil. Biofuels Bioprod Bioref 3: 601-612

Laumonier Y, Edin A, Kanninen M, Munandar AW (2010) Landscape-scale variation in the structure and biomass of the hill dipterocarp forest of Sumatra: Implications for carbon stock assessments. Forest Ecol Manage 259:505-513

Lewandowski I (1998) Propagation method as an important factor in the growth and development of Miscanthus x giganteus. Ind Crop Prod 8:229-245

Lewandowski I, Scurlock JMO, Lindvall E, Christou M (2003) The development and current status of perennial rhizomatous grasses as energy crops in the US and Europe. Biomass Bioenerg 25:335-361

Lindeijer E (2000) Review of land use impact methodologies. J Cleaner Prod 8:273-281

Liu Y, Langer V, Høgh-Jensen H, Egelyng H (2010) Life cycle assessment of fossil energy use and greenhouse gas emissions in Chinese pear production. J Cleaner Prod 18:1423-1430

Luo L, van der Voet E, Huppes G (2009) Life cycle assessment and life cycle costing of bioethanol from sugarcane in Brazil. Renew Sust Energ Rev 13:1613-1619

Macedo IC, Seabra JEA, Silva JEAR (2008) Green house gases emissions in the production and use of ethanol from sugarcane in Brazil: The 2005/2006 averages and a prediction for 2020. Biomass Bioenerg 32: 582595

Malézieux E, Crozat Y, Dupraz C, Laurans M, Makowski D, et al. (2009) Mixing plant species in cropping systems: concepts, tools and models. A review. Agron Sustain Dev 29:43-62

Martinez D, Acevedo P, Kafarov V (2010) Life Cycle Assessment for Joint Production of Biodiesel and Bioethanol from African Palm. Chem Eng Transac 21:1314-1319

Mashoko L, Mbohwa C, Thomas VM (2010) LCA of the South African sugar industry. J Environ Plann Man 53(6): 793-807

Milà i Canals L (2003) Contributions to LCA methodology for agricultural systems, Site-dependency and soil degradation impact assessment. Ph.D. Thesis. Universitat Auto`noma de Barcelona, Spain (available from http://www.tdx.cesca.es/TDX-1222103-154811/).

Milà i Canals L, Burnip GM, Cowell SJ (2006) Evaluation of the environmental impacts of apple production using Life Cycle Assessment (LCA): Case study in New Zealand. Agr Ecosyst Environ 114:226-238

Milà i Canals L, Rigarlsford G, Sim S (2012) Land use impact assessment of margarine. Int J Life Cycle Assess. doi:10.1007/s11367-012-0380-4

Milà i Canals L, Romanyà J, Cowell SJ (2007) Method for assessing impacts on life support functions (LSF) related to the use of 'fertile land' in Life Cycle Assessment (LCA). J Cleaner Prod 15:1426-1440

Mithraratne N, McLaren S, Barber A (2008) Carbon Footprinting for the Kiwifruit Supply Chain - Report on Methodology and Scoping Study. 63

Monti A, Fazio S, Venturi G (2009) Cradle-to-farm gate life cycle assessment in perennial energy crops. European Journal of Agronomy 31:77-84. 
Mouron PJP, Nemecek T, Scholz RW, Weber P (2006a) Management influence on environmental impacts in an apple production system on Swiss fruit farms: Combining life cycle assessment with statistical risk assessment. Agr Ecosyst Environ 311-322

Mouron P, Scholz RW, Nemecek T, Weber O (2006b) Life cycle management on Swiss fruit farms: Relating environmental and income indicators for apple-growing. Ecol Econ 58:561-578

Müller-Wenk R, Brandão M (2010) Climatic impact of land use in LCA-carbon transfers between vegetation/soil and air. Int J Life Cycle Assess 15:172-182

Ndong R, Montrejaud-Vignoles M, Saint Girons O, Gabrielle B, Pirot R, et al. (2009) Life cycle assessment of biofuels from Jatropha curcas in West Africa: a field study. GCB Bioenergy 1: 197-210

Nemecek T, Kägi T (2007) Life Cycle Inventories of Agricultural Production Systems-Ecoinvent report ( No. 15. V2.0). Ecoinvent Center.

Nguyen TLT, Gheewala SH (2008) Life cycle assessment of fuel ethanol from cane molasses in Thailand. Int J Life Cycle Assess 13: 301-311

Nilsson K, Flysjö A, Davis J, Sim S, Unger N, et al. (2010) Comparative life cycle assessment of margarine and butter consumed in the UK, Germany and France. Int J Life Cycle Assess 15:916-926

Ntiamoah A, Afrane G (2008) Environmental impacts of cocoa production and processing in Ghana: life cycle assessment approach. J Cleaner Prod 16:1735-1740

Ometto AR, Hauschild MZ, Roma WNL (2009) Lifecycle assessment of fuel ethanol from sugarcane in Brazil. Int J Life Cycle Assess 14: 236-247

Page G, Kelly T, Minor M, Cameron E (2011) Modeling Carbon Footprints of Organic Orchard Production Systems to Address Carbon Trading: An Approach Based on Life Cycle Assessment. Hort Sci 46:324327

Pandey KK, Pragya N, Sahoo PK (2011): Life cycle assessment of small-scale high-input Jatropha biodiesel production in India. Appl Energ 88: 4831-4839

Papong S, Chom-In T, Noksa-nga S, Malakul P (2010) Life cycle energy efficiency and potentials of biodiesel production from palm oil in Thailand. Energ Policy 38:226-233

Pizzigallo ACI, Granai C, Borsa S (2008) The joint use of LCA and emergy evaluation for the analysis of two Italian wine farms. J Environ Manage 86:396-406

Pleanjai S, Gheewala SH (2009) Full chain energy analysis of biodiesel production from palm oil in Thailand. Appl Energ 86:S209-S214

Pleanjai S, Gheewala SH, Garivait S (2009) Greenhouse gas emissions from the production and use of palm methyl ester in Thailand. Int J Glob Warming 1:418-431

Prasuhn V (2006) Erfassung der PO4- Austräge für die Ökobilanzierung SALCA Phosphor. Agroscope Reckanholz-Tänikon ART. 20 p.

Prueksakorn K, Gheewala SH (2008) Full chain energy analysis of biodiesel from Jatropha curcas L. in Thailand. Environ Sci Technol 42:3388-3393

Prueksakorn K, Gheewala SH, Malakul P, Bonnet S (2010) Energy analysis of Jatropha plantation systems for biodiesel production in Thailand. Energ Sust Dev 14: 1-5 
Ramjeawon T (2004) Life Cycle Assessment of Cane-Sugar on the island of Mauritius. Int J Life Cycle Assess 9(4): $254-260$

Ramjeawon T (2008) Life cycle assessment of electricity generation from bagasse in Mauritius. J Cleaner Prod 16: $1727-1734$

Reijnders L, Huijbregts MAJ (2008) Palm oil and the emission of carbon-based greenhouse gases. J Cleaner Prod 16:477-482

Reinhardt GA, von Falkenstein E (2011) Environmental assessment of biofuels for transport and the aspects of land use Competition. Biomass Bioenerg 35:2315-2322

Renouf MA, Wegener MK, Nielsen LK (2008) An environmental life cycle assessment comparing Australian sugarcane with US corn and UK sugar beet as producers of sugars for fermentation. Biomass Bioenerg 32: $1144-1155$

Renouf MA, Wegener MK, Pagan RJ (2010) Life cycle assessment of Australian sugarcane production with a focus on sugarcane growing. Int J Life Cycle Assess 15: 927-937

Richner W, Oberholzer HR, Freiermuth R, Huguenin O, Walther U (2006) Modell zur Beurteilung des Nitratauswaschungspotenzials in Ökobilanzen-SLACA Nitrat, Agroscope Reckenholz-Tänilon ART, 25p.

Salomone R (2003). Life cycle assessment applied to coffee production: investigating environmental impacts to aid decision making for improvements at company level. Food Agr Environ 1(2):295-300

Sanjuán N, Úbeda L, Clemente G, Mulet A, Girona F (2005) LCA of integrated orange production in the Comunidad Valenciana (Spain). Int J Agr Res Gov Ecol 4(2):15

Schmidt JH (2007) Life cycle inventory of rapeseed oil and palm oil. PhD Thesis: Life cycle inventory report. Department of Development and Planning, Aalborg University, Aalborg, Denmark

Searchinger T, Heimlich R, Houghton RA, Dong F, Elobeid A, et al. (2008) Use of U.S. Croplands for Biofuels Increases Greenhouse Gases Through Emissions from Land-Use Change. Science 319:1238-1240

Siangjaeo S, Gheewala SH, Unnanon K, Chidthaisong A (2011) Implications of land use change on the life cycle greenhouse gas emissions from palm biodiesel production in Thailand. Energ Sust Dev 15:1-7

Silalertruksa T, Gheewala SH (2009) Environmental sustainability assessment of bio-ethanol production in Thailand. Energ 34: 1933-1946

Siles P. Harmand JM, Vaast P (2010). Effects of Inga densiflora on the microclimate of coffee (Coffea arabica L.) and overall biomass under optimal growing conditions in Costa Rica. Agroforest Syst 78:269-286

Sim S, Barry M, Clift R, Cowell SJ (2007) The relative importance of transport in determining an appropriate sustainability strategy for food sourcing. Int J Life Cycle Assess 12:422-431

Stehfest E, Bouwman L (2006) $\mathrm{N}_{2} \mathrm{O}$ and $\mathrm{NO}$ emission from agricultural fields and soils under natural vegetation: summarizing available measurement data and modeling of global annual emissions. Nutr Cycl Agroecosyst 74:207-228

Stichnothe H, Schuchardt F (2011) Life cycle assessment of two palm oil production systems. Biomass Bioenerg 35:3976-3984

Strapatsa AV, Nanos GD, Tsatsarelis CA (2006) Energy flow for integrated apple production in Greece. Agri Ecosyst Environ 116, 176-180 
Tan RR, Culaba AB, Purvis MRI (2004) Carbon balance implications of coconut biodiesel utilization in the Philippine automotive transport sector. Biomass Bioenerg 26: 579-585

Thamsiriroj T, Murphy JD (2009) Is it better to import palm oil from Thailand to produce biodiesel in Ireland than to produce biodiesel from indigenous Irish rape seed? App Energ 86:595-604

Weidema BP (2001) Physical impacts of land use in product life cycle assessment. Denmark

Wetlands International (2010) A quick scan of peatlands in Malaysia. Wetlands International-Malaysia: Petaling Jaya, Malaysia. 74 pp.

Wicke B, Dornburg V, Junginger M, Faaij A (2008) Different palm oil production systems for energy purposes and their greenhouse gas implications. Biomass Bioenerg 32:1322-1337

Xunmin O, Xiliang Z, Shiyan C, Qingfang G (2009): Energy consumption and and GHG emissions of six biofuel pathways by LCA in (the) People’s Republic of China. Appl Energ 86: 197-208

Yee KF, Tan KT, Abdullah AZ, Lee KT (2009) Life cycle assessment of palm biodiesel: Revealing facts and benefits for sustainability. App Energ 86:189-196

Yusoff S, Hansen S (2007) Feasibility Study of Performing an Life Cycle Assessment on Crude Palm Oil Production in Malaysia. Int J Life Cycle Assess 12:50-58

Zulkifli H, Halimah M, Mohd Basri W, Choo YM (2009) Life cycle assessment for FFB production. PIPOC 2009 Palm oil - Balancing Ecologies with Economics, Kuala Lumpur, Malaysia 
Table 1: Overview of the main reviewed studies (70) and their key parameters.

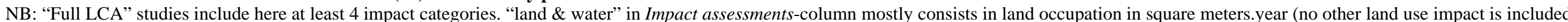
except where specified into brackets) and water consumption in cubic meters (mostly "blue water").

Source of data for farm stage: FS=Field Survey with or without complementary data sources, DB=Data Base/Literature only;

Co-product handling: PA=Physical Allocation by mass (m) or energy (e), EA=Economic Allocation, SE=System Expansion;

Vehicles in well-to-wheel studies: HDV=Heavy-Duty Vehicle, LDV=Light-Duty Vehicle

\begin{tabular}{|c|c|c|c|c|c|c|c|c|c|}
\hline $\begin{array}{l}\text { Products } \\
\text { \& number } \\
\text { of studies }\end{array}$ & Authors \& year & Countries & $\begin{array}{l}\text { Full } \\
\text { LCA }\end{array}$ & Goal \& scope & $\begin{array}{l}\text { Cradle } \\
\text { to... }\end{array}$ & \begin{tabular}{|l|} 
Co- \\
product
\end{tabular} & Functional units & $\begin{array}{l}\text { Farm } \\
\text { stage }\end{array}$ & Impact assessments \\
\hline \multirow[t]{15}{*}{$\begin{array}{l}\text { Palm oil: } \\
18 \text { studies }\end{array}$} & $\begin{array}{l}\text { Achten et al. } \\
\text { 2010b }\end{array}$ & Cameroon & $\mathrm{X}$ & $\begin{array}{l}\text { To assess the environmental impacts of combined palm oil and biodiesel, } \\
\text { i.e. palm methyl ester (PME) } \\
\text { To compare PME with fossil diesel }\end{array}$ & Grave & SE & $1 \mathrm{MJ}$ & FS & $\begin{array}{l}\text { Energy, IPCC } 2006 \\
\text { Lindfors et al. } 1995 \\
\text { Ecosystem quality }\end{array}$ \\
\hline & $\begin{array}{l}\text { Angarita et al. } \\
2009\end{array}$ & $\begin{array}{l}\text { Colombia } \\
\text { Brazil }\end{array}$ & & $\begin{array}{l}\text { To assess the energy balance of palm biodiesel (PME) } \\
\text { To compare the energy balance of two sources of PME }\end{array}$ & Tank & SE & $1 \mathrm{~kg}$ PME & DB & Energy balance \\
\hline & $\begin{array}{l}\text { Choo et al. } \\
2011\end{array}$ & Malaysia & $\mathrm{X}$ & $\begin{array}{l}\text { To assess the environmental impacts of palm oil (CPO) and biodiesel } \\
\text { (PME) }\end{array}$ & $\begin{array}{c}\text { Mill gate } \\
\text { Wheel }\end{array}$ & $\begin{array}{c}\mathrm{SE} \\
\mathrm{PA}(\mathrm{m})\end{array}$ & $\begin{array}{l}1 \text { tonne CPO } \\
1 \text { MJ PME }\end{array}$ & FS & Eco-indicator 99 \\
\hline & $\begin{array}{l}\text { Chuchuoy et al. } \\
2009\end{array}$ & Thailand & & To assess the GHG emission savings of palm oil (CPO) & Mill gate & - & 1 tonne CPO & FS & IPCC 2007 \\
\hline & $\begin{array}{l}\text { de Souza et al. } \\
2010\end{array}$ & Brazil & & $\begin{array}{l}\text { To assess the GHG and energy balances, and carbon payback time of palm } \\
\text { biodiesel (PME) } \\
\text { To compare the studied Brazilian PME to PME from other studies } \\
\end{array}$ & Tank & $\begin{array}{c}\mathrm{SE} \\
\mathrm{PA}(\mathrm{m})\end{array}$ & $\begin{array}{l}1 \text { ha (i.e. } 4 \text { tonnes } \\
\text { PME) }\end{array}$ & FS & $\begin{array}{l}\text { Energy balance } \\
\text { IPCC } 2001 \\
\text { Carbon payback time }\end{array}$ \\
\hline & $\begin{array}{l}\text { Harsono et al. } \\
2011\end{array}$ & Indonesia & & $\begin{array}{l}\text { To compare the GHG and energy balances of palm biodiesel (PME) from } \\
\text { diverse cropping systems in two regions }\end{array}$ & Mill gate & - & 1 tonne PME & FS & $\begin{array}{l}\text { Energy balance } \\
\text { IPCC } 2006 \\
\text { Carbon payback time }\end{array}$ \\
\hline & $\begin{array}{l}\text { Martinez et al. } \\
2010\end{array}$ & Colombia & X & $\begin{array}{l}\text { To assess the environmental impacts of palm biodiesel (PME) using ethanol } \\
\text { from press palm fiber in a plant simulated by Aspen Hysys } 2006.5\end{array}$ & Wheel & - & $\begin{array}{l}80000 \text { tonne PME } \\
\text { B10 in HDV }\end{array}$ & DB & CML 2000 \\
\hline & \begin{tabular}{|l|} 
Nilsson et al. \\
2010
\end{tabular} & - & $\mathrm{X}$ & $\begin{array}{l}\text { To compare the environmental impacts of butter and margarine according to } \\
\text { fat type and content }\end{array}$ & Retailer & $\begin{array}{c}\text { EA } \\
\text { PA(m) }\end{array}$ & $\begin{array}{l}500 \mathrm{~g} \text { of packaged } \\
\text { butter/margarine }\end{array}$ & DB & $\begin{array}{l}\text { CML } 2001 \\
\text { Land }\end{array}$ \\
\hline & $\begin{array}{l}\text { Papong et al. } \\
2010\end{array}$ & Thailand & & To assess the energy balance of palm biodiesel (PME) & Tank & $\begin{array}{c}\text { PA(m,e) } \\
\text { EA }\end{array}$ & $1 \mathrm{~kg}$ PME & FS & Energy balance \\
\hline & $\begin{array}{l}\text { Pleanjai et al. } \\
2009\end{array}$ & Thailand & & $\begin{array}{l}\text { To assess the GHG emissions of palm biodiesel (PME) compared to fossil } \\
\text { diesel for policy making purposes }\end{array}$ & Wheel & $\mathrm{PA}(\mathrm{m})$ & $100 \mathrm{~km}$ by LDV & FS & IPCC 2001 \\
\hline & $\begin{array}{l}\text { Pleanjai and } \\
\text { Gheewala } 2009\end{array}$ & Thailand & & $\begin{array}{l}\text { To assess the energy balance of palm biodiesel (PME) } \\
\text { To compare PME with coconut and Jatropha biodiesels }\end{array}$ & Tank & SE & $\begin{array}{l}1 \text { tonne PME } \\
1 \text { ha }\end{array}$ & FS & Energy balance \\
\hline & $\begin{array}{l}\text { Siangjaeo et al. } \\
2011\end{array}$ & Thailand & & $\begin{array}{l}\text { To assess the GHG emissions of palm biodiesel (PME) considering diverse } \\
\text { previous land uses }\end{array}$ & Mill gate & - & 1 ML PME & FS & $\begin{array}{l}\text { IPCC } 2006 \\
\text { Land (+SOC) }\end{array}$ \\
\hline & \begin{tabular}{|l|} 
Schmidt \\
2007 \\
\end{tabular} & \begin{tabular}{|l|} 
Malaysia \\
Indonesia \\
\end{tabular} & $\mathrm{X}$ & $\begin{array}{l}\text { To compare the environmental impacts of refined palm oil (RPO) and rape } \\
\text { seed oil supplied to Europe }\end{array}$ & Tank & SE & 1 tonne RPO & FS & $\begin{array}{l}\text { EDIP } 97 \\
\text { Land (consequential) }\end{array}$ \\
\hline & $\begin{array}{l}\text { Stichnothe and } \\
\text { Schuchardt } \\
2011\end{array}$ & Malaysia & $\mathrm{X}$ & $\begin{array}{l}\text { To compare the environmental impacts of palm oil with and without } \\
\text { residues treatments }\end{array}$ & Mill gate & SE & $\begin{array}{l}1 \text { tonne Fresh Fruit } \\
\text { Bunch }\end{array}$ & $\overline{\mathrm{DB}}$ & CML 2007 \\
\hline & $\begin{array}{l}\text { Thamsiriroj and } \\
\text { Murphy }\end{array}$ & Thailand & & $\begin{array}{l}\text { To compare energy and GHG balances of biodiesel produced in Ireland } \\
\text { from indigenous rape seed and imported palm oil }\end{array}$ & Tank & SE & $1 \mathrm{GJ}$ & DB & $\begin{array}{l}\text { Energy and GHG } \\
\text { balances }\end{array}$ \\
\hline
\end{tabular}




\begin{tabular}{|c|c|c|c|c|c|c|c|c|c|}
\hline & 2009 & & & & & & & & \\
\hline & $\begin{array}{l}\text { Wicke et al. } \\
2008\end{array}$ & Malaysia & & $\begin{array}{l}\text { To compare GHG emissions of three palm-based energy carriers used in the } \\
\text { Netherlands }\end{array}$ & Grave & $\begin{array}{c}\text { SE } \\
\text { PA/EA }\end{array}$ & $\begin{array}{l}1 \text { kWh electricity } \\
1 \text { MJ fuel }\end{array}$ & FS & $\begin{array}{l}\text { IPCC } 2006 \\
\text { Land (carbon stocks) }\end{array}$ \\
\hline & $\begin{array}{l}\text { Yee et al. } \\
2009\end{array}$ & Malaysia & & $\begin{array}{l}\text { To assess the GHG and energy balances of palm biodiesel (PME) } \\
\text { To compare PME with rape seed methyl ester (RME) }\end{array}$ & Tank & - & 1 tonne PME & DB & $\begin{array}{l}\text { Energy balance } \\
\text { GHG balance }\end{array}$ \\
\hline & $\begin{array}{l}\text { Yusoff and } \\
\text { Hansen } \\
2007\end{array}$ & Malaysia & $\mathrm{X}$ & To assess the environmental impacts of crude palm oil (CPO) & Mill gate & SE & 1 tonne CPO & DB & Eco-indicator 99 \\
\hline \multirow{2}{*}{$\begin{array}{l}\text { Palm oil + } \\
\text { Jatropha: } \\
2 \text { studies }\end{array}$} & $\begin{array}{l}\text { Arvidsson et al. } \\
2011\end{array}$ & $\begin{array}{l}\text { Malaysia } \\
\text { India }\end{array}$ & $\mathrm{X}$ & $\begin{array}{l}\text { To assess the environmental impacts of hydrotreated vegetable oils (HVO) } \\
\text { To compare the impacts of three feedstocks for HVO }\end{array}$ & Wheel & SE & 1 kWh by HDV & DB & EDIP \\
\hline & $\begin{array}{l}\text { Lam et al. } \\
2009\end{array}$ & Malaysia & & To compare biodiesel from palm oil (PME) and Jatropha oil (JME) & Tank & - & 1 tonne PME or JME & DB & $\begin{array}{l}\text { Energy balance } \\
\text { IPCC } 2001\end{array}$ \\
\hline \multirow[t]{10}{*}{$\begin{array}{l}\text { Jatropha: } \\
10 \text { studies }\end{array}$} & $\begin{array}{l}\text { Achten et al. } \\
\text { 2010a }\end{array}$ & India & $\mathrm{X}$ & To compare Jatropha biodiesel (JME) with fossil-fuel & Tank & SE & $1 \mathrm{MJ} J M E$ & FS & Not specified \\
\hline & $\begin{array}{l}\text { Almeida et al. } \\
2011\end{array}$ & $\begin{array}{l}\text { Location- } \\
\text { independent }\end{array}$ & $\mathrm{X}$ & To assess the environmental impacts of Jatropha biodiesel (JME) & Wheel & SE & $1 \mathrm{MJ} J M E$ & FS & Impact 2002+ \\
\hline & $\begin{array}{l}\text { Gmünder et al. } \\
2010\end{array}$ & India & $\mathrm{X}$ & $\begin{array}{l}\text { To assess the environmental impacts of decentralized power generation } \\
\text { plant fuelled by straight Jatropha oil (SJO) } \\
\text { To compare SJO plant with fossil diesel and central photovoltaic plants }\end{array}$ & $\begin{array}{l}\text { Village } \\
\text { bus bar }\end{array}$ & EA & 1 kWh electricity & FS & $\begin{array}{l}\text { CML } 2001 \\
\text { Eco-indicator } 99 \\
\text { Energy balance }\end{array}$ \\
\hline & \begin{tabular}{|l} 
Hou et al. \\
2011
\end{tabular} & China & $\mathrm{X}$ & To compare biodiesel from Jatropha oil (JME), soybean and microalgae & Wheel & PA(m) & $1 \mathrm{MJ} J M E$ & DB & CML 2001 \\
\hline & $\begin{array}{l}\text { Ju and Chen } \\
2011\end{array}$ & China & & To assess the environmental impacts of Jatropha biodiesel (JME) & Tank & - & $1 \mathrm{~J} \mathrm{JME}$ & DB & $\begin{array}{l}\text { Energy and emergy } \\
\text { balances }\end{array}$ \\
\hline & $\begin{array}{l}\text { Ndong et al. } \\
2009\end{array}$ & Ivory Coast & & $\begin{array}{l}\text { To assess the environmental impacts of biodiesel from Jatropha (JME) } \\
\text { To compare JME with fossil fuel or other biofuel types }\end{array}$ & Tank & $\mathrm{PA}(\mathrm{e})$ & $1 \mathrm{MJ}$ JME & FS & $\begin{array}{l}\text { Energy balance } \\
\text { IPCC } 2007\end{array}$ \\
\hline & \begin{tabular}{|l|} 
Pandey et al. \\
2011
\end{tabular} & India & & $\begin{array}{l}\text { To assess the life cycle energy balance and GHG emissions of Jatropha } \\
\text { biodiesel (JME) }\end{array}$ & Wheel & - & 1 ha & FS & $\begin{array}{l}\text { Energy balance } \\
\text { Non-specified IPCC }\end{array}$ \\
\hline & \begin{tabular}{|l|} 
Prueksakorn et \\
al. \\
2010 \\
\end{tabular} & Thailand & & $\begin{array}{l}\text { To compare two alternative Jatropha plantation systems (a perennial one } \\
\text { and an annual one) }\end{array}$ & Tank & - & $\begin{array}{l}1 \text { GJ all outputs } \\
1 \text { ha }\end{array}$ & FS & Energy balance \\
\hline & $\begin{array}{l}\text { Prueksakorn and } \\
\text { Gheewala } \\
2008\end{array}$ & Thailand & & To assess the energy consumption of Jatropha methyl ester (JME) & Tank & $\mathrm{PA}(\mathrm{e})$ & $\begin{array}{l}1 \text { GJ all outputs } \\
1 \text { ha }\end{array}$ & FS & Energy balance \\
\hline & $\begin{array}{l}\text { Xunmin et al. } \\
2009\end{array}$ & China & & $\begin{array}{l}\text { To compare the energy consumption and GHG emissions of various biofuel } \\
\text { pathways including Jatropha biodiesel (JME) }\end{array}$ & Wheel & $\begin{array}{l}\text { Unspeci } \\
\text { fied rule }\end{array}$ & $1 \mathrm{MJ}$ JME & DB & $\begin{array}{l}\text { Energy balance } \\
\text { IPCC } 2001\end{array}$ \\
\hline \multirow[t]{4}{*}{$\begin{array}{l}\text { Sugarcane: } \\
12 \text { studies }\end{array}$} & $\begin{array}{l}\text { Botha and von } \\
\text { Blottnitz } \\
2006\end{array}$ & South Africa & $\mathrm{X}$ & $\begin{array}{l}\text { To compare the impacts of current practice and two prospective ways of } \\
\text { using bagasse for energy purposes }\end{array}$ & Mill gate & SE & 1 ha & DB & $\begin{array}{l}\text { Non-specified CML } \\
\text { Eco-indicator } 95\end{array}$ \\
\hline & $\begin{array}{l}\text { Contreras et al. } \\
2009\end{array}$ & Cuba & $\mathrm{X}$ & $\begin{array}{l}\text { To assess the environmental impacts of cane sugar considering with four } \\
\text { ways of handling co-products }\end{array}$ & Mill gate & SE & $\begin{array}{l}1 \text { daily production } \\
\text { (214 tonne) }\end{array}$ & DB & Eco-indicator 99 \\
\hline & $\begin{array}{l}\text { Groot and } \\
\text { Borén, } \\
2010 \\
\end{array}$ & Thailand & $\mathrm{X}$ & $\begin{array}{l}\text { To assess the environmental impacts of lactide and polylactic acid } \\
\text { biopolymers from sugarcane }\end{array}$ & $\begin{array}{l}\text { Factory } \\
\text { gate }\end{array}$ & SE & 1 tonne material & DB & $\begin{array}{l}\text { CML } 2001 \\
\text { IPCC } 2007\end{array}$ \\
\hline & Luo et al. & Brazil & $\mathrm{X}$ & To compare the impacts of sugarcane ethanol with fossil fuel & Wheel & EA & $1 \mathrm{~km}$ by midsize car & DB & Not specified \\
\hline
\end{tabular}




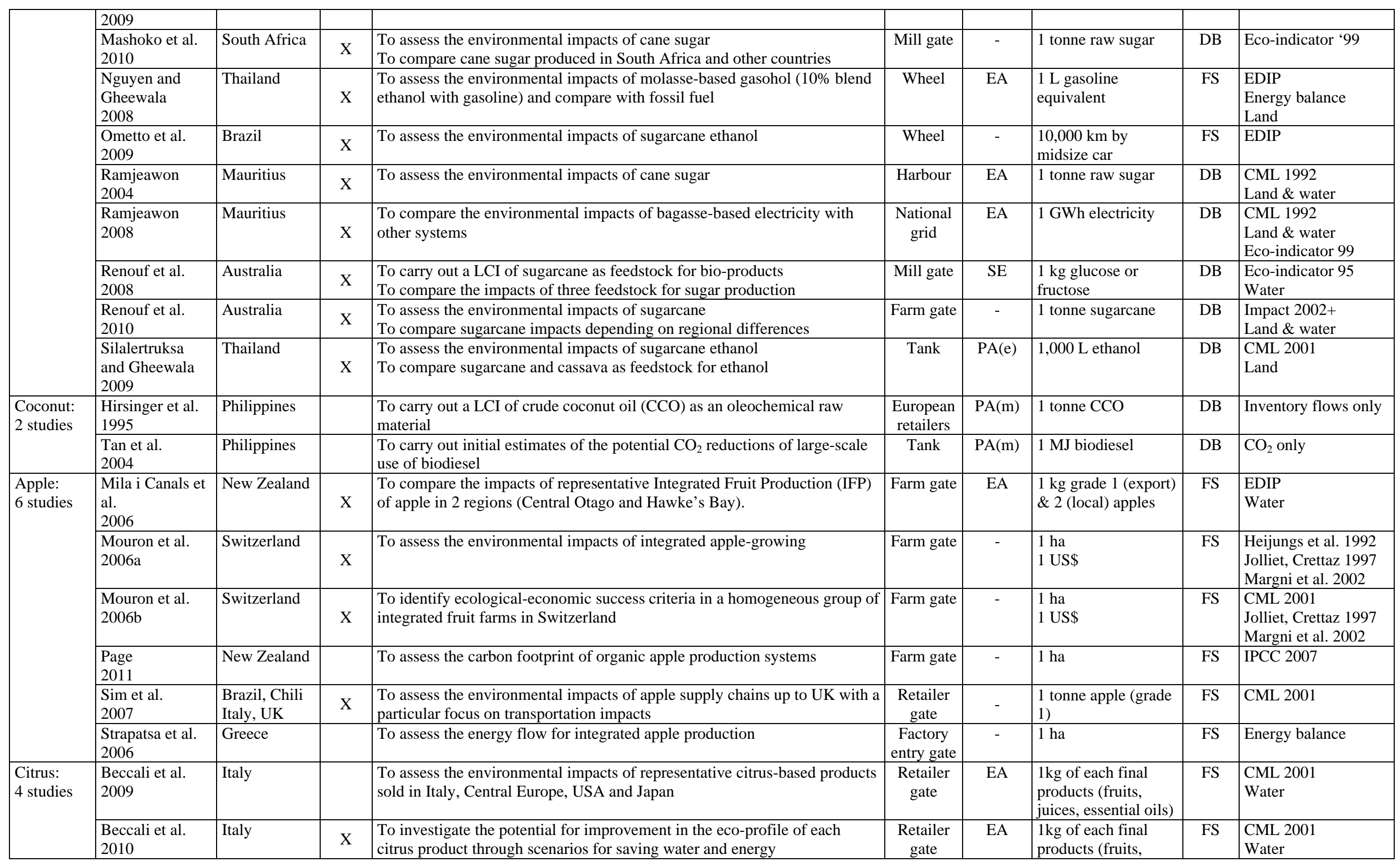




\begin{tabular}{|c|c|c|c|c|c|c|c|c|c|}
\hline & & & & & & & juices, essential oils) & & \\
\hline & $\begin{array}{l}\text { Coltro et al. } \\
2009\end{array}$ & Brazil & & $\begin{array}{l}\text { To calculate the economic flows of frozen concentrated orange juice } \\
\text { (FCOJ) in the two major regions of production in Sao Paulo state }\end{array}$ & \begin{tabular}{c|} 
Factory \\
entry gate
\end{tabular} & - & $\begin{array}{l}1000 \mathrm{~kg} \text { oranges for } \\
\text { FCOJ }\end{array}$ & FS & \\
\hline & $\begin{array}{l}\text { Sanjuan et al. } \\
2005\end{array}$ & Spain & $\mathrm{X}$ & $\begin{array}{l}\text { To assess the environmental impacts of typical integrated production of } \\
\text { oranges ( } 8 \text { management scenarios ) in Comunidad Valenciana }\end{array}$ & Farm gate & - & $\begin{array}{l}1 \text { kg oranges } \\
\text { (Navelina) }\end{array}$ & DB & $\begin{array}{l}\text { CML } 2000 \\
\text { Water }\end{array}$ \\
\hline \multirow[t]{4}{*}{$\begin{array}{l}\text { Grape: } \\
4 \text { studies }\end{array}$} & $\begin{array}{l}\text { Aranda et al. } \\
2005\end{array}$ & Spain & $\mathrm{X}$ & $\begin{array}{l}\text { To reduce the environmental impacts of a bottle of wine by mean of LCA- } \\
\text { based scenario analysis }\end{array}$ & Grave & - & $\begin{array}{l}0.75 \mathrm{~L} \text { bottle of wine } \\
\text { (1kg grape) }\end{array}$ & DB & $\begin{array}{l}\text { Ecoindicator } 99 \mathrm{H} / \mathrm{A} \\
\text { Water }\end{array}$ \\
\hline & $\begin{array}{l}\text { Ardente et al. } \\
2006\end{array}$ & Italy & & $\begin{array}{l}\text { To analyse the peculiarities and drawbacks of the application of the Product } \\
\text { Oriented Environmental Management system (POEMS) to Small and } \\
\text { Medium Enterprises through one case study for an Italian winery company }\end{array}$ & $\begin{array}{l}\text { Retailer } \\
\text { gate }\end{array}$ & - & $\begin{array}{l}0.75 \mathrm{~L} \text { bottle red } \\
\text { wine }\end{array}$ & FS & $\begin{array}{l}\text { Energy balance } \\
\text { GHG balance } \\
\text { Water }\end{array}$ \\
\hline & $\begin{array}{l}\text { Gazulla et al. } \\
2010\end{array}$ & Spain & $\mathrm{X}$ & $\begin{array}{l}\text { To assess the environmental impacts of wine } \\
\text { To compare the impacts with those of other alcoholic table beverages }\end{array}$ & Grave & EA & $\begin{array}{l}0.75 \mathrm{~L} \text { red wine } \\
\text { (Crianza) }\end{array}$ & FS & $\begin{array}{l}\text { CML } 2001 \\
\text { Water }\end{array}$ \\
\hline & \begin{tabular}{|l|} 
Pizzigallo et al. \\
2008
\end{tabular} & Italy & & $\begin{array}{l}\text { To compare organic and conventional wine producing farms using LCA } \\
\text { (emergy evaluation) }\end{array}$ & $\begin{array}{l}\text { Factory } \\
\text { gate }\end{array}$ & - & 1 tonne final product & FS & No LCIA results \\
\hline \multirow[t]{2}{*}{$\begin{array}{l}\text { Olive: } \\
2 \text { studies }\end{array}$} & $\begin{array}{l}\text { Avraamides and } \\
\text { Fatta } \\
2008\end{array}$ & Cyprus & $\mathrm{X}$ & To assess the environmental impacts of extra virgin oil & $\begin{array}{l}\text { Factory } \\
\text { gate }\end{array}$ & EA & $\begin{array}{l}\text { 1 l extra virgin olive } \\
\text { oil }\end{array}$ & FS & $\begin{array}{l}\text { CML } 2000 \\
\text { Eco-indicator } 99 \\
\text { Land }\end{array}$ \\
\hline & $\begin{array}{l}\text { Cappelletti et al. } \\
2010\end{array}$ & Italy & $\mathrm{X}$ & To assess the environmental of packaged green table olives & $\begin{array}{l}\text { Factory } \\
\text { gate }\end{array}$ & - & $\begin{array}{l}100 \mathrm{~kg} \text { packaged } \\
\text { olives }\end{array}$ & FS & CML 2001 \\
\hline $\begin{array}{l}\text { Kiwifruit: } \\
1 \text { study }\end{array}$ & $\begin{array}{l}\text { Page } \\
2011\end{array}$ & New Zealand & & To assess the carbon footprint of organic kiwifruit production systems & $\begin{array}{l}\text { Farm- } \\
\text { gate }\end{array}$ & - & 1 ha & FS & IPCC 2007 \\
\hline \begin{tabular}{|l|} 
Pear: \\
1 study
\end{tabular} & $\begin{array}{l}\text { Liu et al. } \\
2010\end{array}$ & China & & $\begin{array}{l}\text { To assess the fossil energy use and greenhouse gas emission from different } \\
\text { pear production chains in China }\end{array}$ & $\begin{array}{c}\text { Retailer } \\
\text { entry gate }\end{array}$ & - & 1 tonne pears & FS & $\begin{array}{l}\text { Energy balance } \\
\text { IPCC } 2007\end{array}$ \\
\hline $\begin{array}{l}\text { Banana : } \\
1 \text { study }\end{array}$ & $\begin{array}{l}\text { Graefe et al. } \\
2011\end{array}$ & $\begin{array}{l}\text { Costa Rica } \\
\text { Ecuador }\end{array}$ & & $\begin{array}{l}\text { To compare the energy and carbon footprints of ethanol production from } \\
\text { three systems producing banana discard }\end{array}$ & $\begin{array}{l}\text { Plant } \\
\text { gate }\end{array}$ & - & $1 \mathrm{~L}$ ethanol & FS & $\begin{array}{l}\text { Energy balance } \\
\text { Carbon balance }\end{array}$ \\
\hline \multirow[t]{6}{*}{$\begin{array}{l}\text { Coffee: } \\
6 \text { studies }\end{array}$} & $\begin{array}{l}\text { Busser and } \\
\text { Jungbluth } \\
\text { 2009a }\end{array}$ & Brazil & $\mathrm{X}$ & $\begin{array}{l}\text { To assess the environmental impacts of flexible packaging taking into } \\
\text { account consumption patterns at home or office }\end{array}$ & Grave & - & 1 cup of coffee & DB & CML 2001 \\
\hline & $\begin{array}{l}\text { Coltro et al. } \\
2006\end{array}$ & Brazil & & $\begin{array}{l}\text { To conduct a LCI of Brazilian green coffee and compare different cropping } \\
\text { systems }\end{array}$ & $\begin{array}{l}\text { Factory } \\
\text { gate }\end{array}$ & - & $\begin{array}{l}1 \text { tonne green coffee } \\
\text { for export }\end{array}$ & FS & - \\
\hline & $\begin{array}{l}\text { de Monte et al. } \\
2005\end{array}$ & - & $\mathrm{X}$ & $\begin{array}{l}\text { To assess the environmental impacts of coffee packaging (coffee production } \\
\text { and processing not included) }\end{array}$ & Grave & & $1 \mathrm{~kg}$ packed coffee & DB & Ecoindicator 95 \\
\hline & $\begin{array}{l}\text { Hanssen et al. } \\
2007\end{array}$ & - & & $\begin{array}{l}\text { To test the potential of using LCA for a whole sector rather than individual } \\
\text { product (factor } 10 \text { concept) }\end{array}$ & Grave & - & $\begin{array}{l}\text { 147L coffee/person } \\
\text { in Norway in } 2000\end{array}$ & DB & $\begin{array}{l}\text { Energy balance } \\
\text { GHG emissions }\end{array}$ \\
\hline & $\begin{array}{l}\text { Humbert et al. } \\
2009\end{array}$ & \begin{tabular}{|l|} 
Brazil, \\
Colombia \\
Vietnam
\end{tabular} & $\mathrm{X}$ & $\begin{array}{l}\text { To compare the environmental impacts of spray dried, filter and capsule } \\
\text { coffees }\end{array}$ & Grave & - & $\begin{array}{l}1 \text { cup of coffee } \\
(1 \mathrm{dL})\end{array}$ & DB & Impact 2002+ \\
\hline & $\begin{array}{l}\text { Salomone } \\
2003\end{array}$ & - & $\mathrm{X}$ & To assess the environmental impacts of coffee for a coffee company & Grave & SE & 1kg packaged coffee & DB & CML 2000 \\
\hline $\begin{array}{l}\text { Cocoa: } \\
1 \text { study }\end{array}$ & $\begin{array}{l}\text { Ntiamoah and } \\
\text { Afrane } \\
2008\end{array}$ & Ghana & $\mathrm{X}$ & To assess the environmental impacts of cocoa & $\begin{array}{l}\text { Factory } \\
\text { gate }\end{array}$ & - & $1 \mathrm{~kg}$ processed cocoa & DB & CML 2001 \\
\hline
\end{tabular}




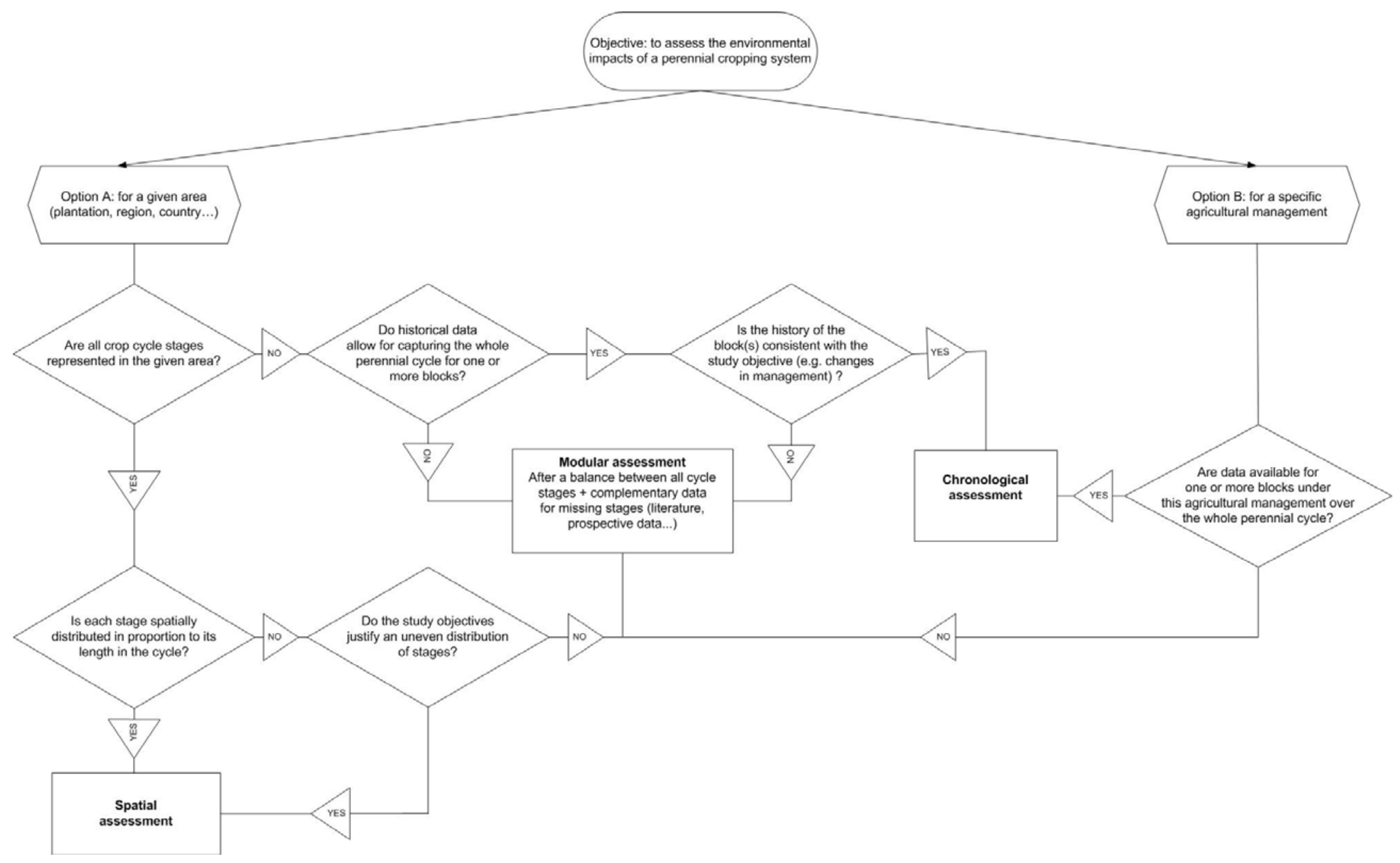

Figure 1: Decision tree to model the perennial crop cycle within LCA. Block means a unit of plantation with a unique planting date, planting material from the same origin and homogeneous climatic and edaphic conditions. Representative crop cycle stages generally encompass immature phase, productive phase, and declining production phase but it may vary with the perennial crop. 